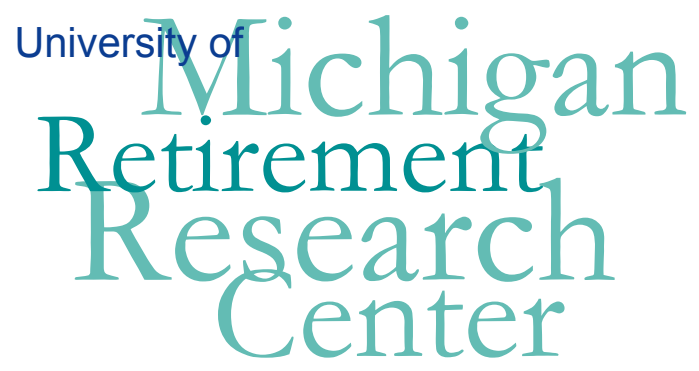

Working Paper

WP 2004-082

Understanding Patterns of Social Security Benefit Receipt, Pensions Incomes, Retirement and Saving by Race, Ethnicity, Gender and Marital Status: A Structural Approach

Alan L. Gustman and Thomas L. Steinmeier

\begin{tabular}{|l|l|l|l|l}
\hline $\mathrm{M}$ & $\mathrm{R}$ & Project \#: UM03-13 \\
\hline
\end{tabular} 


\title{
Understanding Patterns of Social Security Benefit Receipt, Pensions Incomes, Retirement and Saving by Race, Ethnicity, Gender and Marital Status: A Structural Approach
}

\author{
Alan L. Gustman \\ Dartmouth College and NBER
}

Thomas L. Steinmeier

Texas Tech University

July 2004

\author{
Michigan Retirement Research Center \\ University of Michigan \\ P.O. Box 1248 \\ Ann Arbor, MI 48104
}

\section{Acknowledgements}

This work was supported by a grant from the Social Security Administration through the Michigan Retirement Research Center (Grant \# 10-P96362-5). The opinions and conclusions are solely those of the authors and should not be considered as representing the opinions or policy of the Social Security Administration or any agency of the Federal Government.

\section{Regents of the University of Michigan}

David A. Brandon, Ann Arbor; Laurence B. Deitch, Bingham Farms; Olivia P. Maynard, Goodrich; Rebecca McGowan, Ann Arbor; Andrea Fischer Newman, Ann Arbor; Andrew C. Richner, Grosse Pointe Park; S. Martin Taylor, Gross Pointe Farms; Katherine E. White, Ann Arbor; Mary Sue Coleman, ex officio 


\title{
Understanding Patterns of Social Security Benefit Receipt, Pensions Incomes, Retirement and Saving by Race, Ethnicity, Gender and Marital Status: A Structural Approach
}

\author{
Alan Gustman \\ Thomas L. Steinmeier
}

\begin{abstract}
In this paper we use data from the Health and Retirement Study to examine differences in retirement behavior, wealth, Social Security and pension benefits by race and gender. The differences observed among groups are sometimes substantial. We then estimate models jointly explaining retirement and wealth by race and gender. We decompose differences in outcomes into those due to differences in parameters of the preference function for leisure and goods, time preference rates, and those due to differences in the circumstances of the members of each group. By circumstances we mean both the opportunity set, and factors that determine the disutility of continued work, such as health status. We find that differences in outcomes among white, black and Hispanic males are not due to differences in preferences for leisure and goods consumption, but are due both to differences in time preference and to differences in circumstances. Differences in outcomes between men and women are primarily due to differences in preferences.
\end{abstract}

\section{Authors' Acknowledgement}

This paper was supported by a grant from the U.S. Social Security Administration (SSA) to the Michigan Retirement Research Center, UM 03-13. The opinions and conclusions are solely those of the authors and should not be construed as representing the opinions or policy of SSA, the Michigan Retirement Research Center, or the National Bureau of Economic Research. Alan L. Gustman is Loren Berry Professor of Economics at Dartmouth College, Department of Economics, Hanover, N.H. 03755 (alan.1.gustman@dartmouth.edu). Thomas L. Steinmeier is Professor of Economics, Texas Tech University, Department of Economics, Lubbock, Texas 79409 (Thomas.Steinmeier@TTU.edu). 


\section{Introduction.}

In this paper we use data from the Health and Retirement Study to examine differences in retirement behavior, wealth, Social Security and pension benefits by race and gender. The differences observed among groups are sometimes substantial. We then estimate models jointly explaining retirement and wealth by race and gender. We decompose differences in outcomes into those due to differences in parameters of the preference function and those due to differences in the circumstances of the members of each group. By circumstances we mean both the opportunity set, and factors that determine the disutility of continued work, such as health status.

The paper begins with a descriptive analysis. It examines retirement outcomes, Social Security incomes, pensions and other wealth. Social Security is further decomposed into AIME and PIA. Distributions are generated for demographic groups delineated by race, ethnicity, gender and marital status.

After examining the differences among groups in these variables, we fit structural retirement models to data for each group and consider the causes of retirement behavior within each group. The approach involves fitting a joint structural model of retirement and wealth for each group individually, and examining the reasons for differences in outcomes. The elements

of the budget constraint, Social Security, pensions and wage offers for full and part time work, as well as health status, age and year of birth, are allowed to differ among the groups. They exert separate influences on retirement from those of preferences of those who fall within each group.

A decomposition analysis allows us to determine the reasons for differences in outcomes, and to determine the likely effects of aggregating across categories on the reliability of the estimates obtained with models of retirement. 
We find that differences in circumstances promote later retirement by black and Hispanic men relative to whites, while differences in time preferences have the opposite effect. Higher time preference means that actuarial adjustments for postponing benefit receipt is not as attractive for minorities. Differences in outcomes between men and women are primarily due to differences in preferences, which lead to earlier retirements for women.

Section II examines the descriptive data. The retirement model to be estimated is presented in Section III. Section IV presents the basic estimates of the parameters of the structural model. Section $\mathrm{V}$ examines the separate influences of the preference functions and circumstances, due to opportunity sets, health status and age. Section VI concludes.

\section{Descriptive Analysis}

This study uses data from the first six waves of The Health and Retirement Study (HRS), a longitudinal survey designed to allow explicit measurement of these different constraints. ${ }^{1}$ The survey is taken every two years, so the data cover the period 1992 through 2002. These data cover 12,652 persons from households with a respondent who was 51 to 61 years old in 1992. The study also uses restricted, linked employer provided pension plan descriptions and Social Security earnings records matched with respondents in 1992.

The dependent retirement variable is based on hours of work. ${ }^{2}$ The percentages retired from full-time work and completely retired are calculated as percentages among those respondents who had retirement status observations at each particular age. ${ }^{3}$

\footnotetext{
${ }^{1}$ The Health and Retirement Study is supported principally by a grant from the National Institute on Aging to the Institute for Social Research at the University of Michigan. Additional support is provided by the Social Security Administration and other federal agencies.

${ }^{2}$ Individuals working over 30 hours per week and more than 1560 hours per year are counted as full-time. Individuals working more than 100 hours per year but less than 25 hours per week or 1250 hours per year are counted as part time, and individuals not doing any work are counted as fully retired. Individuals who fall between full time and part time or between part time and retired are classified on the basis of self reports.
} 


\section{A. Retirement Statistics}

Throughout this paper we are going to report results for career workers. To be classified as a career worker, between age 40 and the last year of full time work, a person must have worked full time in at least half the years. In addition, one must be observed to have worked full time in some year at or after turning age 50. The baseline data for all career workers in the HRS is presented in Table 1. The first column of numbers reports retirements from full time work. The second column reports the flow into full retirement. Thus the first column also includes those who leave full time work for partial retirement and directly into full retirement, while the last column includes the flows from full time work directly into full retirement, as well as the flow from partial retirement into full retirement. From columns 1 and 2 we see the familiar sharp spike in retirements at age 62 , fourteen percent of career workers leaving full retirement and twelve and a half percent entering full retirement. The smaller spikes in retirements at age 65 are also readily apparent. These numbers, which are really pseudo retirement rates, are calculated as the difference in succeeding ages in the overall level of retirements, as reported in Columns 3

and 4. The difference between columns 3 and 4 is the fraction who are in partial retirement. As can be seen from Table 1, the fraction partially retired is about nine percent at age 60 , fourteen percent at age 65 , and somewhat smaller thereafter.

To provide some perspective on the effect of using career workers as the basis for the retirement measures employed throughout the rest of this study, we also have calculated retirement outcomes for all persons in the HRS, whatever their work history. These data are

\footnotetext{
${ }^{3}$ A person who is on disability insurance is considered to be out of the retirement calculation. Such a person is not included in either the numerator or the denominator of the retirement measure. For example, if a person worked during the first two surveys, and then entered DI on the third survey, this person is in the calculation in the first two surveys, but is out of the numerator and denominator once having joined DI.
} 
presented in Appendix Table 1. The fraction retired is much higher when the full population is used instead of the career workers, especially at younger ages when an hours based definition of retirement implies that those with little early commitment to the labor force are nevertheless properly categorized as retired. Table 2 calculates the differences in the share of the relevant population retired when the sample is confined to career workers vs. all persons. At age 50, the fraction retired from full time work for career plus noncareer workers exceeds the fraction retired from full time work for career workers by almost 25 percentage points. The difference in the fraction completely retired is about 17 percentage points between estimates based on the two different population bases.

From this point on we report disaggregated results. All disaggregated retirement rates pertain to Career workers. Tables 3 and 4 report the baseline retirement results from Table 1 separately for men and women. Once again, the sharp spikes at ages 62 and 65 are readily apparent. The differences in levels of retirement between men and women are reported in Table 5. From column 1 we see that women are 5.7 percentage points more likely to be retired from full time work than men at age 50; 9.4 percentage points more likely to be retired than men at age $60 ; 8.5$ percent more likely at age 62 ; and 6.7 percent more likely at age 65 . The differences in complete retirement are slightly smaller than for retirement from full time work, except at age 65.

Tables 6, 7 and 8 disaggregate retirement rates for white, black and Hispanic males respectively. Once again each data set shows a sharp spike in retirements at age 62, 14.9 percentage points for white males, 15.8 percentage points for black males, and 12.7 percentage points for Hispanic males. However, the retirement spike is much smaller for white males at age 65 than it is for black and Hispanic males. For whites the age 65 spike in retirements from full 
time work is 8.4 percentage points, while for black and Hispanic males it is 15.2 and 12 percentage points, about the same size spike at 65 as at 62 .

Differences in the percentages retired from full time work, and the percentages retired completely for males, by race, are reported in Table 9 . With exceptions at a couple of ages, blacks are more likely to be retired than whites. The largest difference is 8 percentage points at age 62 in the percent completely retired. Differences between Hispanic and white men are are reported in the last two columns of Table 9. After age 60, Hispanic men are less likely to be retired than are white men. The differences rise to over 11 percentage points for 63 and 64 year old men.

Comparable baseline statistics are reported by race for women in Tables 10 through 12, with differences in retirement levels reported in Table 13 between black and white women, and Hispanic and white women. For all three groups, there is a sharp spike in retirements at age 62 . The sharpest spike seen for any group at 62 is that for Hispanic women, with 20.6 percent retiring exactly at age 62 , compared to 13.2 percent and 14.3 percent of black and white women at age 62 . The spike in retirements from full time work at age 65 is very small for white women at just under 8 percentage points. For black women the spike is 7.3 percentage points. But for Hispanic women, the spike is 14.5 percentage points. Although there is strong evidence of retirement at the early and normal entitlement ages of Social Security for all groups, the strongest relation among all groups is found for Hispanic women.

In Table 13 we see only small differences in retirement levels between black and white women. The differences also bounce a lot between white and Hispanic women. Hispanic women are slightly less likely to be retired from full time work than white women through age 55. Then for most of the years through age 63 , they are more likely to be retired than white 
women, sometimes substantially so. At older ages, the cells get thinner, making the story less clear.

Appendix Tables 2 through 5 present the basic indicators of retirement levels and retirement flows for married and single males, and for married and single females respectively. Table 14 reports the differences in retirement levels between married and singles, for men and women respectively. Married men are much less likely to be retired than single men, while married women are much more likely to be retired than single women. When we focus on the differences in the percent retired from full time work, for those between the ages of 58 and 62 , these differences reach double digit levels. They are larger in absolute terms for women than men, but substantial for each.

\section{B. Wealth, Social Security Benefits and Pensions}

Table 15 provides descriptive statistics on wealth, Social Security benefits, pension coverage and pension wealth by gender, race and marital status. In the model we will estimate below, wealth is not a determinant of retirement, but is jointly determined with retirement. Social Security benefits and pension benefits actually received depend on work and retirement choices, but are framed by the rules governing Social Security and pensions.

Line 1 of Table 15 reports average values for all career workers in the sample. As of the initial wave of the Health and Retirement Survey, 1992, mean wealth is $\$ 200,000$ for the sample, outside of pensions and Social Security. Median wealth is $\$ 98,000$. The annualized value of AIME at age 62 averages $\$ 20,500$ and the annualized value of the PIA averages $\$ 8,900$. Over 70 percent have a pension. Of those with positive benefits from DB plans, the annual DB benefit averages $\$ 12,000$, while for those with a DC account, the value at retirement is $\$ 94,000$. We do not discuss the distributions of Social Security benefits or wealth here, or the adequacy of 
replacement rates in retirement. In earlier work we found that for about three quarters of the HRS population, replacement rates appeared to be adequate, and that Social Security was not as redistributive among families as the PIA formula would suggest. For a discussion of these issues, see Gustman and Steinmeier (1999 and 2001).

Turn now to compare the results for career workers who are men vs. women. Remembering that wealth is a household concept, wealth held by women is 80 percent of the wealth held by men. AIME for women is less than two thirds the AIME for men among those who fit our definition of career workers. PIA for women is about three quarters of the PIA of men, which means that few of these women will be collecting spouse benefits. Five percent fewer women are covered by a pension than men. DB pension benefits at retirement received by women are 60 percent of the value of DB pension benefits received by men, while their DC pension balances are worth 43 percent of the balances for men. Thus the differences in DB pension values are in line with earnings differences while the difference in DC values is wider than the difference in earnings.

Next compare the results for black and Hispanic men to the results for white men. Overall, the differences in nonpension, nonSocial Security wealth holdings between Black and Hispanic men on the one hand, and white men on the other, and in the values of DC accounts, are wider than the difference in covered earnings over their lifetimes. In contrast, the differences in Social Security benefits, pension coverage, and the values of payments under DB plans for those receiving positive payments are narrower than the differences in earnings. To be more specific, wealth held by black and Hispanic men amounts to about a third of the wealth held by white men. Black men earned about three quarters of the level earned by white men, while Hispanic men earned about 70 percent of the level earned by white men. Blacks and Hispanics will enjoy 
about four fifths of the PIA received by white men. The difference in pension coverage between black and white men is about 5 percentage points, but it is 25 percentage points between Hispanic and white men. Defined benefit pensions held by black men will pay just over 80 percent of the pensions received by white men, while the pensions held by Hispanic men will pay just under two thirds the benefits received by white men. DC accounts held by black men are worth about 58 percent of the value of the accounts held by whites, while the comparable figure for Hispanic men is 50 of the value of DC plans held by white men.

Differences in wealth levels and DC balances are wider than differences in earnings between black and white women, while differences in Social Security AIME, pension coverage and DB pension values are narrower than differences in earnings - indeed, DB pension values are higher for black women receiving benefits than they are for white women. Differences in wealth levels, pension coverage, and DB pension values are wider than differences in earnings between Hispanic and white women. Specifically, black women have about 40 percent of the wealth of white women, while Hispanic women average about 56 percent of the wealth of white women, with a smaller value when median wealth is compared. Black women earned about 94 percent of the earnings of white women, with Hispanic women earning about 86 percent of the earnings of white women. Black women's AIME is about 96 percent of the value for white women, while the ration of Hispanic women is 86 percent. There is only a one percentage point difference in pension coverage between white and black women, while the difference is 20 percentage points between Hispanic and white women. Pensions are six percent higher for black women with DB benefits than for white women, while Hispanic women have DB pensions worth about three quarters of the value of DB pensions for white women. Black women have three 
fourths the DC balances of white women, while Hispanic women have over 85 percent of the DC balances of white women.

Although single men have 11 percent lower earnings (as measured by AIME) than married men, and single women have seven percent lower earnings (AIME) than married women, the differences in wealth holdings are much greater between married and singles. Singles actually have higher DC balances than married. Remembering that the wealth figures are not prorated in married households, in the case of males, the differences in wealth holdings are almost two to one, while for women they are bigger than two to one, so if taken on a per capita basis, wealth levels held by married and singles are not so greatly out of line with differences in earnings. Indeed, given the predominance of two earner households, wealth levels may be disproportionately lower in two earner households in comparison to earnings.

Otherwise, except for a ten percentage point difference in pension coverage, other differences between married and singles are not substantial.

\section{The Basic Retirement Model}

The basic model is a structural, dynamic model of retirement and saving that we have developed in previous work. ${ }^{4}$ This model specifies a lifetime expected utility function with the time path of consumption and leisure as arguments. The constraints include an asset accumulation equation and an uncertain lifetime. Workers are allowed to partially retire, usually in different jobs from those held in prime working age. As a result, work when partially retired typically pays a lower wage rate. Social Security enters as income in the asset accumulation equation in the years that benefits are received. The current utility value of the future benefits is,

${ }^{4}$ We have used the model for policy analysis, in one case simulating the effects of raising the Social Security early entitlement age (Gustman and Steinmeier, forthcoming) and in another, simulating certain proposals made by the President's Commission to Strengthen Social Security (Gustman and Steinmeier, 2002). A full description of the methodology in estimating the model and using it to simulate policy is found in our earlier work. 
of course, heavily dependent on the worker's time preference rate. Retirement preferences and time preferences are both allowed to be heterogeneous among workers.

The utility function is given by

$$
\mathrm{U}=\int_{0}^{\mathrm{T}} \mathrm{e}^{-\rho \mathrm{t}} \sum_{\mathrm{m}=1}^{3}\left\{\mathrm{~S}_{\mathrm{mt}}\left[\frac{1}{\alpha} \mathrm{C}_{\mathrm{mt}}^{\alpha}+\mathrm{e}^{\beta \mathrm{X}_{\mathrm{t}}+\varepsilon} \mathrm{L}_{\mathrm{mt}}^{\gamma}\right]\right\} \mathrm{dt} \quad \alpha, \gamma<1 .
$$

In this equation, $\mathrm{T}$ is the maximum lifespan and $\mathrm{m}$ refers to the family structure at time $\mathrm{t}$ (both spouses alive, only the husband alive, or only the wife alive). $s_{m} t$ is the probability of family structure $\mathrm{m}$ at time $\mathrm{t}, \mathrm{C}$ is consumption, and $\mathrm{L}$ is the leisure, which takes on a value of 0 for full-time work, 1 for full retirement, and $\frac{1}{2}$ for partial retirement. ${ }^{5} \mathrm{X}$ includes a constant, age, health status, and vintage. The age variable and worsening health cause leisure to become gradually more attractive as the individual ages. The time preference term $\rho$ is a fixed effect, and the leisure preference term $\varepsilon$ is a random effect drawn from a normal distribution. $\gamma$ is also random effect, taken so that the term $L^{\gamma}$ comes from the exponential distribution $f\left(L^{\gamma}\right)=\mathrm{ke}^{\delta \mathrm{L}^{\gamma}}$ defined over the range $\frac{1}{2}$ to 1 , which is the theoretically acceptable range for $\mathrm{L}^{\gamma}$. $\mathrm{k}$ is the constant necessary for the density function to integrate to unity, as it must. Since partial retirement seems to become relatively more attractive as the individuals age, we specify $\delta$ to be increasing in age: $\delta=\delta_{0}+\delta_{\mathrm{a}}$ (Age). Estimation is based on the general method of simulated moments. The simulated moments come from the average moments of solving the model for 10,000 draws of the random effects.

\footnotetext{
${ }^{5}$ In recognition that consumption is more valuable while both spouses are alive, the consumption function is adjusted so that the marginal utility for a surviving spouse is approximately equal to that for a couple consuming $40 \%$ more.
} 
The model is estimated for each specified demographic group from the Health and Retirement Study using observations for the first six waves of the survey, every other year from 1992 through 2002. Earnings profiles are taken from Social Security records or, if these are not available, from the retrospective information in the respondent surveys. Actual earnings from 1992 through 2002 are taken from the respondent survey. Future potential earnings are projected on the basis of tenure and experience coefficients of earnings regressions. Pension benefits, conditional on tenure in the job providing the pension, are based on information in the summary pension descriptions, provided by the employers. Social Security benefits are based on the earnings histories and figured according to the Social Security rules.

The model has 8 parameters to be estimated. These include the consumption parameter $\alpha$, four elements of $\beta$ including the constant and coefficients for age, poor health, and birth year, two elements of $\delta$ including a constant and a coefficient of age, and the standard deviation of retirement preferences given by $\sigma_{\varepsilon}$. The model is estimated using the generalized method of simulated moments. ${ }^{6}$ This method essentially chooses the parameters so as to minimize the differences between a set of observed statistics (moments) in the sample and the values of those statistics that would be implied by the model. In the minimization, the moments are weighted so as to provide the most precise estimates possible with the data.

The estimation uses 46 moments, including the fraction of the sample working full time and the fraction fully retired at various ages. Additional moments are calculated at various ages for specific groups in the sample, including early and late birth cohorts, high and low lifetime earners, and those with poor health. If the model is correct, the q-statistic comes from a $\chi^{2}$ distribution with the degrees of freedom given by the number of moments minus the number of parameters. In the present model, this translates into a $\chi^{2}$ distribution with 38 degrees of

\footnotetext{
${ }^{6}$ For a description, see Greene (2000).
} 
freedom (46 moments less 8 parameters), which has a 95\% confidence bound of approximately 53.4 .

The estimation also calculates a value of $\rho_{\mathrm{i}}$, the time preference rate, for each individual in the sample. The values of $\rho_{\mathrm{i}}$ are calculated so that for the parameter values, the assets that are calculated from the model for each individual are equal to the assets (including financial, real estate, and business assets) actually observed in 1992. The resulting distributions of $\rho$ implies a wide variation in the rates of time preference for different individuals.

As in our recent work, the model is capable of simulating most of the spike in retirements at age 62 , despite the fact that there are no age dummy variables included in the model, and that the Social Security benefit formula is actuarially fair around age 62 .

\section{Estimates of the Structural Models}

Estimates of the parameters of the structural models for men and women are presented in Tables 16 and 17. These tables are for married men and married women who have bee married for the long term, where long term marriage is defined as not having a prior marriage after the age of 35. All of the key parameters are significant.

There are considerable differences in the preference parameters between men and women. Most notable are the differences in the coefficients on the age variables for $\beta$, suggesting women will be less sensitive to incentives from Social Security and other rewards than men. There also are differences in the parameters associated with health status, with women less sensitive to poor health than men. To judge the effects of these parameter differences on retirements, in the next section we will conduct a number of simulations.

We also tried to estimate the differences in retirement preferences by race for men. We began by estimating the model for white males in long term marriages. Parameters are close in 
value to those presented in Table 16, which provided a hint of the results to come. We then attempted to estimate the retirement model for married black males. There were too few observations to allow convergence. The same was true for runs for Hispanic males.

Accordingly, we pooled the data for married males of all races, and added four variables to the preference function for minority status. Two dummy variables indicated the person was black or Hispanic, and two variables reflecting an interaction between minority status and age. As seen in Table 18, the coefficients on these dummy variables are not close to significant at conventional levels.

We should note that although we use the same utility function parameters for different ethnic groups due to the failure find that the dummy variables for black and Hispanic males were significant, there are clear differences among these three groups in time preferences. Using the combined parameters, $57.6 \%$ of whites have time preferences of below $10 \%$, plus or minus $2.8 \%$, blacks have $34.6 \%$ below $10 \%$, plus or minus $5.4 \%$, and Hispanics have $25.8 \%$ below $10 \%$, plus or minus $6.2 \%$. The numbers are little affected if we use the model with specific parameters for each group. These results undoubtedly arise from the fact that whites are more likely to have financial wealth.

As a result, when analyzing differences by race and ethnicity for men, we will be focusing on results analyzing the effects of differences in what we can call circumstances, which include both differences in the values for the variables in the utility function and the budget line, and differences in time preference rates. Here we use the same parameters in the utility function for white males, black males and Hispanic males, allowing the time preference rates and budget lines to differ. 


\section{Simulations to Separate the Retirement Effects of Preference Parameters from Those of Individual Circumstances.}

In this section we separate the effects on retirements due to variation of individual circumstances by gender, race and ethnicity from those of the parameters of the utility function. Here we define individual circumstances as health, age, vintage and elements of the budget set.

Tables 19 presents the results of simulations of the effects on both retirement outcomes retirement from full time work and full retirement -- of the different utility function parameters estimated separately for men and women, as well as the effects of the different circumstances unique to men and women. Thus these retirement outcomes are generated with the utility function parameters for men and the circumstances for men and then women, and then the utility function parameters for women, and the circumstances for men and then women.

Tables 20 and 21 present the differences in retirement outcomes from changing the utility function and keeping the circumstances constant, and changing the circumstances, but keeping the utility function constant. Table 20 pertains to retirements from full time work, while Table 21 pertains to complete retirements. Column 1 in each table presents the actual differences in retirement outcomes between women and men, showing the considerable tendency for women to retire earlier than men. The differences in column 2 compare outcomes using the utility function and circumstances for women minus the utility function and circumstances for men. This fully simulates the sources of differences in retirement tendencies between women and men. The model overstates the difference in retirements for women from age 56 to 62 , turning a twelve to sixteen percentage point differential into an 18 to 22 percent differential. Otherwise, it does a good job of simulating the reasons for differences in retirement rates between women and men. 
We present basic Oaxaca decompositions. Columns 3 and 6 are one decomposition and columns 4 and 5 are the other. The 4,5 decomposition says that the utility function explains practically the entire difference, with the budget sets playing only a small role. The 3,6 decomposition says that the utility function parameters overexplain the difference, with the budget sets actually working in the reverse direction. It is entirely possible for the two ways to do an Oaxaca decomposition to give different results, so this is not necessarily a failure of method. The general message is that the utility function parameters are much more important relative to circumstances in explaining the differences between the retirements of men vs. women.

Since the parameters of the utility functions are statistically indistinguishable among white, black and Hispanic men, but time preference rates are not, Table 22 reports the joint effects of differences in time preferences and circumstances. This calculation uses a utility function in which there are no dummy variables for race or ethnicity, and no interactions of race and ethnicity with age. ${ }^{7}$ The outcome reported is the probability of complete retirement. Tables 23 and 24 decompose the total effects into those due to differences in circumstances (Table 23) and to differences in time preference (Table 24). These findings indicate that differences in circumstances promote later retirement by black and Hispanic men relative to whites, while differences in time preferences have the opposite effect. Because the effects of differences in time preference may be substantial, it will be important for studies of retirement among men to standardize for the effects of differences in time preference among men from different racial and ethnic backgrounds. This finding is in contrast to the findings with regard to preferences for consumption goods vs. leisure, which do not seem to differ among groups.

\footnotetext{
${ }^{7}$ Appendix Table 6 reports results using the utility function estimates which include the (insignificant) coefficients on measures of the impact of race and ethnicity. Outcome levels are reported by race and ethnicity for both retirement from full time work and full retirement.
} 


\section{Conclusion}

This paper has used data from the Health and Retirement Study to examine differences in retirement behavior, wealth, Social Security and pension benefits by race and gender. The differences observed among groups are sometimes substantial. We estimated models jointly explaining retirement and wealth by race and gender. We decomposed differences in outcomes into those due to differences in parameters of the preference function and those due to differences in the circumstances of the members of each group. Circumstances include both the opportunity set, and factors that determine the disutility of continued work, such as health status.

Because of limited numbers of black and Hispanic married males, we pooled the data for married males of all races, and added four variables for minority status to the preference function for leisure. Two dummy variables indicated the person was black or Hispanic, and two variables reflected an interaction between minority status and age. Jointly, these four variables are statistically not significant. However, the distribution of time preferences is statistically different among the groups, so we report the effects of differences in circumstances vs. differences in time preferences. Differences in circumstances promote earlier retirement by black and Hispanic men relative to whites, while differences in time preferences have the opposite effect.

Next we consider the results of simulations of the effects on retirement outcomes of the different preference function parameters estimated separately for men and women, as well as the effects of the different circumstances unique to men and women. Thus these retirement outcomes are generated with the preference function parameters for men and the circumstances for men and then women, and then the preference function parameters for women, and the circumstances for men and then women. Differences in preferences provide the major explanation for the earlier retirement of women. That is, women retire earlier than men due not 
to differences in health or the budget set, but primarily due to differences in preferences for market work.

In addition to providing an in depth analysis of differences in wealth, Social Security and pensions by gender and race, these findings also lead to a recommendation on methodology. In conducting studies of retirement and saving, researchers need not allow for differences in parameters by race and ethnicity reflecting preferences for leisure and consumption; but time preference rates do differ by race and ethnicity and should be incorporated in any analysis of retirement. Researchers should also allow for differences in preference function parameters between men and women. 


\section{References}

Greene, William H. 2000. Econometric Analysis, Fourth Edition. Upper Saddle River: Prentice Hall.

Gustman, Alan L., Olivia S. Mitchell, and Thomas L. Steinmeier. 1995. "Retirement Measures in the Health and Retirement Study". Journal of Human Resources 30, Supplement: S57 to S83.

Gustman, Alan L. and Thomas L. Steinmeier. 1983. "Minimum Hours Constraints and Retirement Behavior". Contemporary Policy Issues, a supplement to Economic Inquiry: 77-91. . 1984a. "Modeling the Retirement Process for Evaluation and Research". Monthly Labor Review (107)7: 26-33. . 1984b. "Partial Retirement and the Analysis of Retirement Behavior". Industrial and Labor Relations Review 37: 403-415. . 1986a. "A Structural Retirement Model," Econometrica 54(3):

$555-584$.

1986b. "A Disaggregated Structural Analysis of Retirement by Race, Difficulty of Work and Health". Review of Economics and Statistics 67(3): 509-513. 1999. "Effects of Pensions on Savings: Analysis with Data From

the Health and Retirement Study". In Carnegie-Rochester Conference Series on Public Policy, Volume 50 (July, 1999b), pp. 271-326.

. 2000. "Retirement Outcomes in the Health and Retirement Study”. Social Security Bulletin, Perspectives 64(4).

. 2001. "How Effective Is Redistribution Under the Social Security benefit Formula". Journal of Public Economics. Volume 82(1), October, pp. 1-28.

. 2002. "Retirement Effects of Proposals by the President's Commission to Strengthen Social Security". NBER Working Paper No. 10030. . Forthcoming. "The Social Security Early Entitlement Age In A Structural Model of Retirement and Wealth". Journal of Public Economics. Also available as NBER Working Paper 9183. September. 
Table 1: Retirements for Career Workers, Both Genders, All Races, All Marital Status Groups

\begin{tabular}{|c|c|c|c|c|c|}
\hline & Retir & nents & $\begin{array}{l}\text { Perce } \\
\text { From }\end{array}$ & it Retired & \\
\hline & From Full & Into Full & Full & & \\
\hline & Time & Time & Time & Completely & Observations \\
\hline & Work & Retirement & Work & Retired & by Age \\
\hline Age & & & & & \\
\hline 50 & 7.4 & 5.6 & 7.4 & 5.6 & 1344 \\
\hline 51 & 1.3 & 0.6 & 8.7 & 6.2 & 1835 \\
\hline 52 & 1.4 & 0.6 & 10.1 & 6.8 & 2351 \\
\hline 53 & 2.4 & 2.4 & 12.5 & 9.1 & 2714 \\
\hline 54 & 2.6 & 1.8 & 15.1 & 10.9 & 3044 \\
\hline 55 & 4.0 & 3.1 & 19.1 & 14.0 & 3342 \\
\hline 56 & 2.1 & 1.6 & 21.2 & 15.6 & 3696 \\
\hline 57 & 2.2 & 1.6 & 23.4 & 17.2 & 3866 \\
\hline 58 & 3.1 & 2.2 & 26.5 & 19.4 & 4031 \\
\hline 59 & 3.8 & 2.9 & 30.3 & 22.3 & 4166 \\
\hline 60 & 6.0 & 4.9 & 36.3 & 27.2 & 4112 \\
\hline 61 & 7.1 & 5.9 & 43.5 & 33.1 & 3666 \\
\hline 62 & 14.3 & 12.6 & 57.7 & 45.8 & 3298 \\
\hline 63 & 6.4 & 4.5 & 64.1 & 50.3 & 2970 \\
\hline 64 & 5.0 & 5.7 & 69.2 & 56.0 & 2626 \\
\hline 65 & 8.8 & 7.2 & 77.9 & 63.2 & 2241 \\
\hline 66 & 3.7 & 2.9 & 81.6 & 66.1 & 1884 \\
\hline 67 & 2.6 & 3.3 & 84.2 & 69.4 & 1568 \\
\hline 68 & 2.5 & 1.9 & 86.6 & 71.3 & 1265 \\
\hline 69 & 1.7 & 3.1 & 88.4 & 74.4 & 945 \\
\hline
\end{tabular}

Observations: 8768 
Table 2: Difference in Retirement Rates by Career Status:

Rates for Career Plus Noncareer Workers Minus Rates for Career Workers Percent Retired

From Full

Time

Work

Age

50

51

52

53

54

55

56

57

58

59

60

61

62

63

64

65

66

67

68

69
24.6

23.2

20.6

19.5

18.3

16.5

15.8

15.6

14.9

14.0

12.9

11.1

7.9

6.5

5.7

3.9

3.0

2.5

2.1

1.6

\section{Completely}

Retired

$$
16.7
$$

15.4

14.1

13.5

12.7

11.4

11.5

11.2

11.0

10.5

10.1

8.6

6.2

5.9

5.3

4.2

3.7

2.9

2.7

2.1 
Table 3: Retirements for Career Workers, Males, All Races, All Marital Status Groups Retirements Percent Retired

\begin{tabular}{|c|c|c|c|c|c|}
\hline & \multicolumn{5}{|c|}{ From } \\
\hline & From Full & Into Full & Full & & \\
\hline & Time & Time & Time & Completely & Observations \\
\hline & Work & Retirement & Work & Retired & by Age \\
\hline Age & & & & & \\
\hline 50 & 3.9 & 3.1 & 3.9 & 3.1 & 514 \\
\hline 51 & 1.8 & 1.2 & 5.7 & 4.3 & 810 \\
\hline 52 & 1.5 & 0.9 & 7.2 & 5.3 & 1141 \\
\hline 53 & 2.1 & 1.5 & 9.2 & 6.8 & 1373 \\
\hline 54 & 2.5 & 1.7 & 11.8 & 8.5 & 1577 \\
\hline 55 & 3.6 & 2.7 & 15.4 & 11.2 & 1776 \\
\hline 56 & 2.3 & 1.7 & 17.7 & 12.9 & 2032 \\
\hline 57 & 1.9 & 1.6 & 19.5 & 14.5 & 2154 \\
\hline 58 & 3.4 & 2.7 & 23 & 17.2 & 2254 \\
\hline 59 & 3.2 & 1.9 & 26.2 & 19.2 & 2391 \\
\hline 60 & 6.2 & 5.1 & 32.4 & 24.2 & 2386 \\
\hline 61 & 7.1 & 6.0 & 39.5 & 30.2 & 2157 \\
\hline 62 & 14.9 & 12.8 & 54.4 & 42.9 & 2003 \\
\hline 63 & 6.2 & 4.1 & 60.5 & 47.0 & 1845 \\
\hline 64 & 5.8 & 5.9 & 66.3 & 52.9 & 1682 \\
\hline 65 & 9.3 & 7.4 & 75.6 & 60.2 & 1474 \\
\hline 66 & 3.9 & 3.4 & 79.6 & 63.6 & 1278 \\
\hline 67 & 3.0 & 3.6 & 82.6 & 67.2 & 1079 \\
\hline 68 & 2.7 & 1.8 & 85.3 & 69.0 & 912 \\
\hline 69 & 2.6 & 4.5 & 87.9 & 73.4 & 730 \\
\hline
\end{tabular}

Observations: 5059 
Table 4: Retirements for Career Workers, Females, All Races, All Marital Status Groups

\begin{tabular}{|c|c|c|c|c|c|}
\hline & Retir & lents & $\begin{array}{l}\text { Perce } \\
\text { From }\end{array}$ & t Retired & \\
\hline & From Full & Into Full & Full & & \\
\hline & Time & Time & Time & Completely & Observations \\
\hline & Work & Retirement & Work & Retired & by Age \\
\hline Age & & & & Age & \\
\hline 50 & 9.6 & 7.1 & 9.6 & 7.1 & 830 \\
\hline 51 & 1.5 & 0.5 & 11.1 & 7.6 & 1025 \\
\hline 52 & 1.7 & 0.6 & 12.8 & 8.2 & 1210 \\
\hline 53 & 3.1 & 3.4 & 15.9 & 11.6 & 1341 \\
\hline 54 & 2.7 & 2.0 & 18.6 & 13.6 & 1467 \\
\hline 55 & 4.8 & 3.6 & 23.4 & 17.2 & 1566 \\
\hline 56 & 2.1 & 1.7 & 25.5 & 18.9 & 1664 \\
\hline 57 & 2.7 & 1.7 & 28.2 & 20.6 & 1712 \\
\hline 58 & 2.7 & 1.7 & 31.0 & 22.3 & 1777 \\
\hline 59 & 4.8 & 4.4 & 35.8 & 26.6 & 1775 \\
\hline 60 & 6.0 & 4.7 & 41.8 & 31.3 & 1726 \\
\hline 61 & 7.3 & 6.0 & 49.1 & 37.4 & 1509 \\
\hline 62 & 13.8 & 12.7 & 62.9 & 50.1 & 1295 \\
\hline 63 & 7.0 & 5.5 & 70.0 & 55.6 & 1125 \\
\hline 64 & 4.2 & 6.0 & 74.2 & 61.7 & 944 \\
\hline 65 & 8.1 & 7.2 & 82.3 & 68.8 & 767 \\
\hline 66 & 3.5 & 2.4 & 85.8 & 71.3 & 606 \\
\hline 67 & 1.9 & 2.9 & 87.7 & 74.2 & 489 \\
\hline 68 & 2.4 & 3.1 & 90.1 & 77.3 & 353 \\
\hline 69 & -0.3 & 0.3 & 89.8 & 77.7 & 215 \\
\hline
\end{tabular}

Observations: 3709 
Table 5: Difference in Retirement Rates by Gender:

Rates for Females Minus Rates for Males

\begin{tabular}{rrr}
\multicolumn{3}{c}{ Percent Retired } \\
\multicolumn{3}{c}{ From } \\
& Full & \\
& Time & Completely \\
& Work & Retired \\
Age & & \\
50 & 5.7 & 4.0 \\
51 & 5.4 & 3.3 \\
52 & 5.6 & 2.9 \\
53 & 6.7 & 4.8 \\
54 & 6.8 & 5.1 \\
55 & 8.0 & 6.0 \\
56 & 7.8 & 6.0 \\
57 & 8.7 & 6.1 \\
58 & 8.0 & 5.1 \\
59 & 9.6 & 7.4 \\
60 & 9.4 & 7.1 \\
61 & 9.6 & 7.2 \\
62 & 8.5 & 7.2 \\
63 & 9.5 & 8.6 \\
64 & 7.9 & 8.8 \\
65 & 6.7 & 8.6 \\
66 & 6.2 & 7.7 \\
67 & 5.1 & 7.0 \\
68 & 4.8 & 8.3 \\
69 & 1.9 & 4.3
\end{tabular}


Table 6: Retirements for Career Workers, Males, Whites, All Marital Status Groups

\begin{tabular}{|c|c|c|c|c|c|}
\hline & Retir & lents & $\begin{array}{l}\text { Perc } \\
\text { From }\end{array}$ & t Retired & \\
\hline & From Full & Into Full & Full & & \\
\hline & Time & Time & Time & Completely & Observations \\
\hline & Work & Retirement & Work & Retired & by Age \\
\hline Age & & & & & \\
\hline 50 & 3.4 & 2.7 & 3.4 & 2.7 & 414 \\
\hline 51 & 1.6 & 1.1 & 4.9 & 3.7 & 647 \\
\hline 52 & 1.3 & 0.9 & 6.2 & 4.6 & 898 \\
\hline 53 & 2.0 & 1.3 & 8.2 & 5.9 & 1099 \\
\hline 54 & 2.5 & 1.4 & 10.7 & 7.3 & 1280 \\
\hline 55 & 4.1 & 3.4 & 14.8 & 10.7 & 1454 \\
\hline 56 & 1.7 & 1.4 & 16.5 & 12.0 & 1654 \\
\hline 57 & 1.7 & 1.6 & 18.2 & 13.6 & 1754 \\
\hline 58 & 4.2 & 3.2 & 22.4 & 16.8 & 1847 \\
\hline 59 & 3.2 & 1.7 & 25.6 & 18.5 & 1955 \\
\hline 60 & 6.8 & 5.5 & 32.4 & 24.0 & 1959 \\
\hline 61 & 7.2 & 6.0 & 39.6 & 30.1 & 1777 \\
\hline 62 & 14.9 & 12.1 & 54.5 & 42.2 & 1669 \\
\hline 63 & 6.5 & 4.3 & 61.1 & 46.5 & 1554 \\
\hline 64 & 6.3 & 6.4 & 67.3 & 52.9 & 1420 \\
\hline 65 & 8.4 & 6.8 & 75.7 & 59.7 & 1242 \\
\hline 66 & 3.9 & 3.7 & 79.6 & 63.3 & 1069 \\
\hline 67 & 3.0 & 3.5 & 82.6 & 66.9 & 902 \\
\hline 68 & 2.6 & 1.6 & 85.2 & 68.5 & 765 \\
\hline 69 & 2.8 & 4.4 & 88.1 & 72.9 & 612 \\
\hline
\end{tabular}

Observations: 3987 
Table 7: Retirements for Career Workers, Males, Blacks, All Marital Status Groups

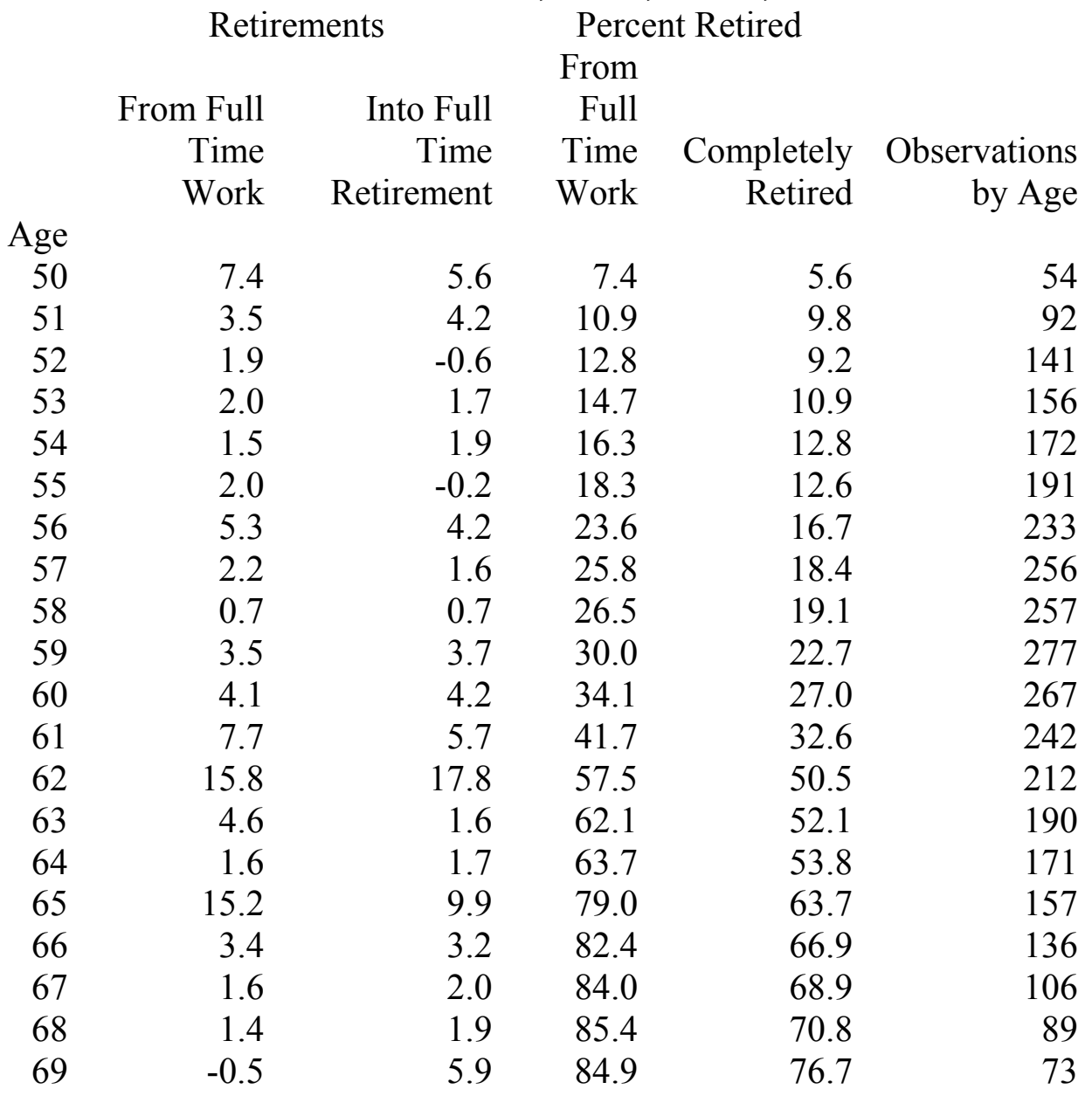

Observations: 667 
Table 8: Retirements for Career Workers, Males, Hispanics, All Marital Status Groups

\begin{tabular}{rrrrr}
\multicolumn{2}{c}{ Retirements } & \multicolumn{3}{c}{ Percent Retired } \\
From Full & Into Full & From \\
Time & Time & Time & Completely & Observations \\
Work & Retirement & Work & Retired & by Age
\end{tabular}

Age

$\begin{array}{rrrrrr}50 & 4.3 & 4.3 & 4.3 & 4.3 & 46 \\ 51 & 1.3 & -1.5 & 5.6 & 2.8 & 71 \\ 52 & 2.2 & 3.1 & 7.8 & 5.9 & 102 \\ 53 & 4.0 & 3.4 & 11.9 & 9.3 & 118 \\ 54 & 4.9 & 5.9 & 16.8 & 15.2 & 125 \\ 55 & 0.8 & 0.1 & 17.6 & 15.3 & 131 \\ 56 & 3.8 & 2.0 & 21.4 & 17.2 & 145 \\ 57 & 3.6 & 1.5 & 25.0 & 18.8 & 144 \\ 58 & -0.3 & 0.6 & 24.7 & 19.3 & 150 \\ 59 & 2.4 & 1.4 & 27.0 & 20.8 & 159 \\ 60 & 1.7 & 1.1 & 28.8 & 21.9 & 160 \\ 61 & 5.3 & 5.7 & 34.1 & 27.5 & 138 \\ 62 & 12.7 & 12.6 & 46.7 & 40.2 & 122 \\ 63 & 2.8 & 5.4 & 49.5 & 45.5 & 101 \\ 64 & 6.5 & 5.0 & 56.0 & 50.5 & 91 \\ 65 & 12.0 & 12.1 & 68.0 & 62.7 & 75 \\ 66 & 6.0 & -1.0 & 74.0 & 61.6 & 73 \\ 67 & 6.3 & 7.4 & 80.3 & 69.0 & 71 \\ 68 & 5.9 & 3.4 & 86.2 & 72.4 & 58 \\ 69 & 4.9 & 3.1 & 91.1 & 75.6 & 45\end{array}$

Observations: 405 
Table 9: Differences in Retirement Rates By Race and Ethnicity for Males: Rates for Blacks and Hispanics Minus Rates for Whites.

\begin{tabular}{|c|c|c|c|c|}
\hline & Black I & Minus White & Hispa & $\begin{array}{l}\text { ic Minus } \\
\text { Jhite }\end{array}$ \\
\hline & & Percen & Retired & \\
\hline & From & & From & \\
\hline & Full & & Full & \\
\hline & Time & Completely & Time & Completely \\
\hline Age & Work & Retired & Work & Retired \\
\hline 50 & 4.0 & 2.9 & 0.9 & 1.6 \\
\hline 51 & 6.0 & 6.1 & 0.7 & -0.9 \\
\hline 52 & 6.6 & 4.6 & 1.6 & 1.3 \\
\hline 53 & 6.5 & 5.0 & 3.7 & 3.4 \\
\hline 54 & 5.6 & 5.5 & 6.1 & 7.9 \\
\hline 55 & 3.5 & 1.9 & 2.8 & 4.6 \\
\hline 56 & 7.1 & 4.7 & 4.9 & 5.2 \\
\hline 57 & 7.6 & 4.8 & 6.8 & 5.2 \\
\hline 58 & 4.1 & 2.3 & 2.3 & 2.5 \\
\hline 59 & 4.4 & 4.2 & 1.4 & 2.3 \\
\hline 60 & 1.7 & 3.0 & -3.6 & -2.1 \\
\hline 61 & 2.1 & 2.5 & -5.5 & -2.6 \\
\hline 62 & 3.0 & 8.3 & -7.8 & -2.0 \\
\hline 63 & 1.0 & 5.6 & -11.6 & -1.0 \\
\hline 64 & -3.6 & 0.9 & -11.3 & -2.4 \\
\hline 65 & 3.3 & 4.0 & -7.7 & 3.0 \\
\hline 66 & 2.8 & 3.6 & -5.6 & -1.7 \\
\hline 67 & 1.4 & 2.0 & -2.3 & 2.1 \\
\hline 68 & 0.2 & 2.3 & 1.0 & 3.9 \\
\hline 69 & -3.2 & 3.8 & 3.0 & 2.7 \\
\hline
\end{tabular}


Table 10 Retirements for Career Workers, Females, Whites, All Marital Status Groups

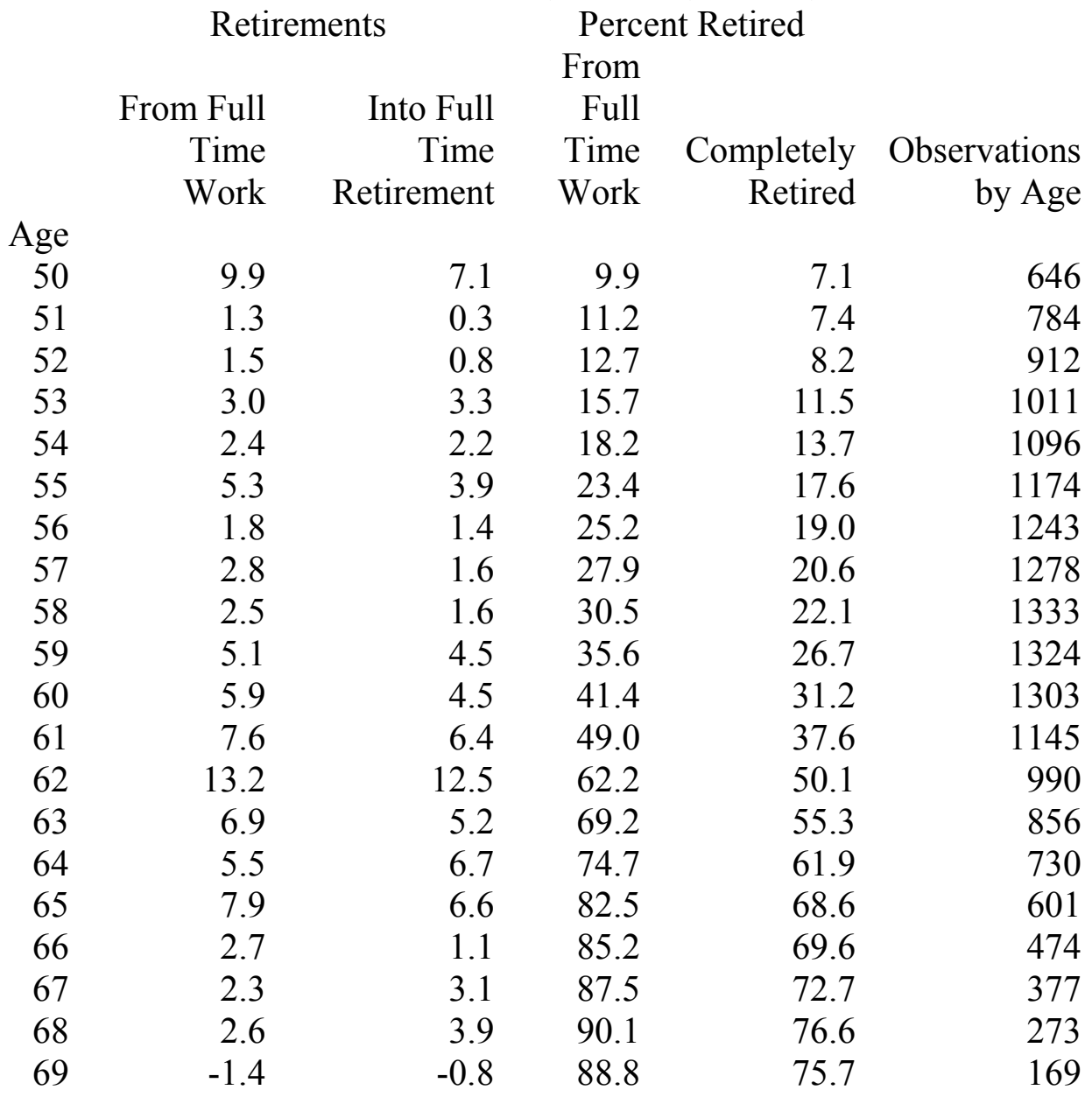

Observations: 2720 
Table 11 Retirements for Career Workers, Females, Blacks, All Marital Status Groups

\begin{tabular}{|c|c|c|c|c|c|}
\hline & Reti & ients & $\begin{array}{l}\text { Perc } \\
\text { From }\end{array}$ & $t$ Retired & \\
\hline & From Full & Into Full & Full & & \\
\hline & Time & Time & Time & Completely & Observations \\
\hline & Work & Retirement & Work & Retired & by Age \\
\hline Age & & & & & \\
\hline 50 & 9.0 & 7.6 & 9.0 & 7.6 & 145 \\
\hline 51 & 2.5 & 1.2 & 11.5 & 8.7 & 183 \\
\hline 52 & 2.0 & 0.2 & 13.5 & 9.0 & 223 \\
\hline 53 & 4.6 & 4.8 & 18.0 & 13.7 & 255 \\
\hline 54 & 2.2 & 0.6 & 20.3 & 14.3 & 286 \\
\hline 55 & 3.2 & 1.8 & 23.5 & 16.1 & 298 \\
\hline 56 & 2.1 & 2.0 & 25.6 & 18.1 & 320 \\
\hline 57 & 1.4 & 1.1 & 27.0 & 19.2 & 333 \\
\hline 58 & 4.2 & 2.6 & 31.2 & 21.9 & 343 \\
\hline 59 & 4.9 & 4.2 & 36.1 & 26.1 & 341 \\
\hline 60 & 8.1 & 6.5 & 44.2 & 32.6 & 319 \\
\hline 61 & 6.3 & 3.8 & 50.5 & 36.4 & 275 \\
\hline 62 & 14.3 & 12.1 & 64.8 & 48.5 & 233 \\
\hline 63 & 7.0 & 6.8 & 71.8 & 55.3 & 206 \\
\hline 64 & 0.7 & 5.0 & 72.6 & 60.4 & 164 \\
\hline 65 & 7.3 & 6.3 & 79.8 & 66.7 & 129 \\
\hline 66 & 7.8 & 8.6 & 87.6 & 75.2 & 105 \\
\hline 67 & -1.3 & 0.9 & 86.4 & 76.1 & 88 \\
\hline 68 & 2.0 & -1.1 & 88.3 & 75.0 & 60 \\
\hline 69 & 2.8 & 4.4 & 91.2 & 79.4 & 34 \\
\hline
\end{tabular}

Observations: 740 
Table 12 Retirements for Career Workers, Females, Hispanics, All Marital Status Groups

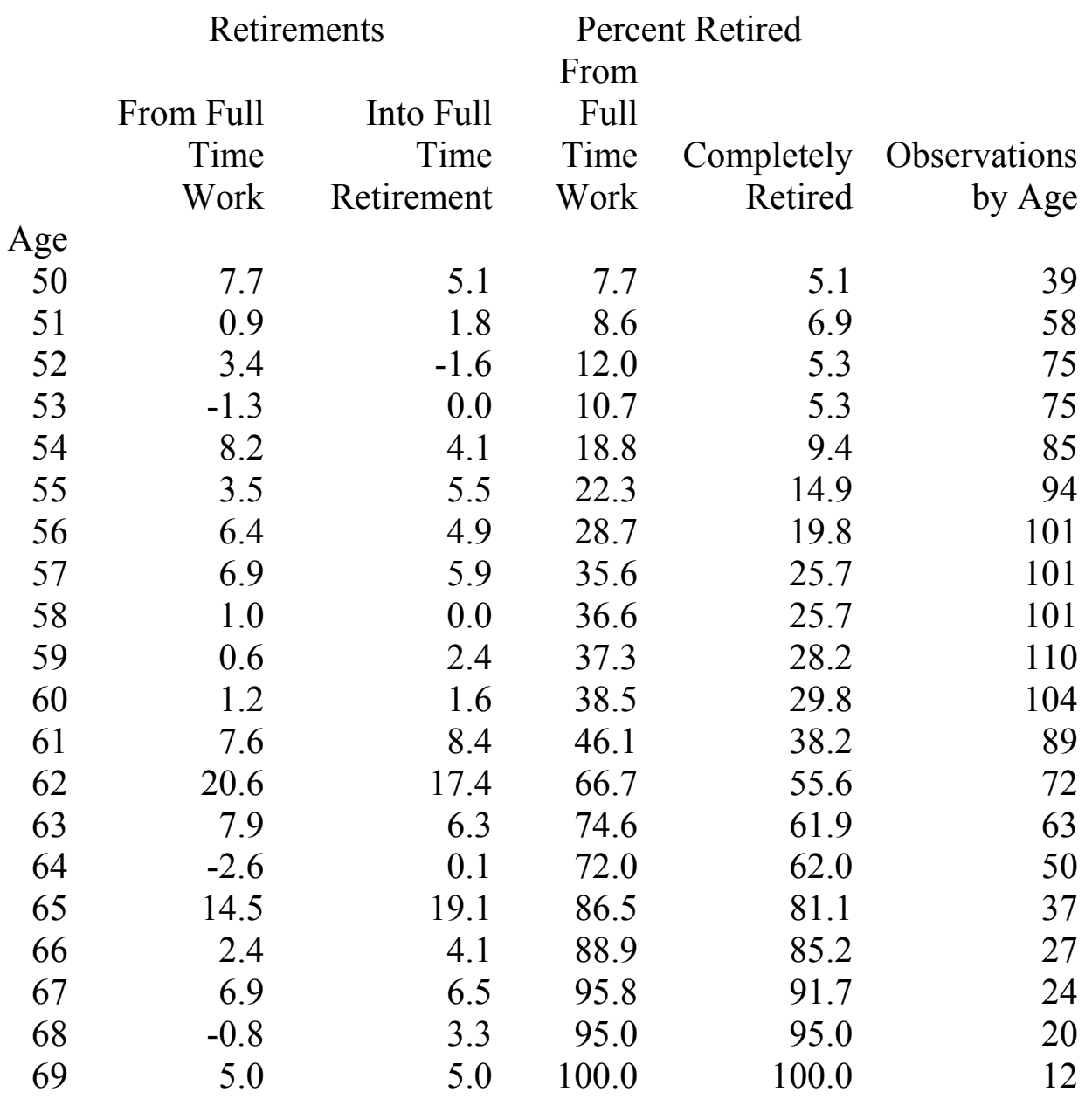

Observations: 249 
Table 13: Differences in Retirement Rates By Race and Ethnicity for Females: Rates for Blacks and Hispanics Minus Rates for Whites.

\begin{tabular}{|c|c|c|c|c|}
\hline & Black & Minus White & Hisp & $\begin{array}{l}\text { iic Minus } \\
\text { Thite }\end{array}$ \\
\hline & & Percen & Retired & \\
\hline & From & & From & \\
\hline & Full & & Full & \\
\hline & Time & Completely & Time & Completely \\
\hline Age & Work & Retired & Work & Retired \\
\hline 50 & -0.9 & 0.5 & -2.2 & -2.0 \\
\hline 51 & 0.3 & 1.3 & -2.6 & -0.5 \\
\hline 52 & 0.8 & 0.8 & -0.7 & -2.9 \\
\hline 53 & 2.3 & 2.2 & -5.0 & -6.2 \\
\hline 54 & 2.1 & 0.6 & 0.6 & -4.3 \\
\hline 55 & 0.1 & -1.5 & -1.1 & -2.7 \\
\hline 56 & 0.4 & -0.9 & 3.5 & 0.8 \\
\hline 57 & -0.9 & -1.4 & 7.7 & 5.1 \\
\hline 58 & 0.7 & -0.2 & 6.1 & 3.6 \\
\hline 59 & 0.5 & -0.6 & 1.7 & 1.5 \\
\hline 60 & 2.8 & 1.4 & -2.9 & -1.4 \\
\hline 61 & 1.5 & -1.2 & -2.9 & 0.6 \\
\hline 62 & 2.6 & -1.6 & 4.5 & 5.5 \\
\hline 63 & 2.6 & 0.0 & 5.4 & 6.6 \\
\hline 64 & -2.1 & -1.5 & -2.7 & 0.1 \\
\hline 65 & -2.7 & -1.9 & 4.0 & 12.5 \\
\hline 66 & 2.4 & 5.6 & 3.7 & 15.6 \\
\hline 67 & -1.1 & 3.4 & 8.3 & 19.0 \\
\hline 68 & -1.8 & -1.6 & 4.9 & 18.4 \\
\hline 69 & 2.4 & 3.7 & 11.2 & 24.3 \\
\hline
\end{tabular}


Table 14: Differences in Retirement Rates By Marital Status for Males and Females: Rates for Married Minus Rates for Singles.

\begin{tabular}{|c|c|c|c|c|}
\hline & \multicolumn{2}{|c|}{ Males } & \multicolumn{2}{|c|}{ Females } \\
\hline & \multicolumn{4}{|c|}{ Percent Retired } \\
\hline & From & & From & \\
\hline & Full & & Full & \\
\hline & Time & Completely & Time & Completely \\
\hline Age & Work & Retired & Work & Retired \\
\hline 50 & -1.7 & -1.0 & 1.9 & -0.4 \\
\hline 51 & -1.0 & -1.6 & 3.9 & 1.6 \\
\hline 52 & -4.4 & -3.2 & 7.1 & 4.3 \\
\hline 53 & -10.0 & -7.8 & 7.8 & 5.3 \\
\hline 54 & -7.9 & -6.7 & 6.2 & 6.4 \\
\hline 55 & -8.6 & -6.8 & 9.0 & 9.1 \\
\hline 56 & -8.9 & -8.3 & 9.4 & 8.3 \\
\hline 57 & -6.7 & -5.6 & 12.1 & 8.1 \\
\hline 58 & -10.6 & -9.6 & 15.1 & 11.1 \\
\hline 59 & -10.6 & -9.6 & 13.2 & 10.0 \\
\hline 60 & -10.2 & -10.0 & 12.9 & 9.2 \\
\hline 61 & -11.6 & -9.8 & 13.4 & 11.7 \\
\hline 62 & -11.5 & -9.0 & 16.8 & 17.3 \\
\hline 63 & -6.1 & -4.5 & 16.3 & 15.4 \\
\hline 64 & -0.6 & -5.1 & 15.0 & 13.1 \\
\hline 65 & -0.1 & -8.2 & 11.1 & 12.5 \\
\hline 66 & 2.2 & -6.8 & 8.7 & 9.3 \\
\hline 67 & 0.0 & -9.1 & 9.8 & 8.1 \\
\hline 68 & -1.4 & -6.1 & 8.9 & 8.5 \\
\hline 69 & 0.8 & -6.4 & 6.6 & 4.1 \\
\hline
\end{tabular}


Table 15: Descriptive Statistics on Wealth, Social Security and Pensions

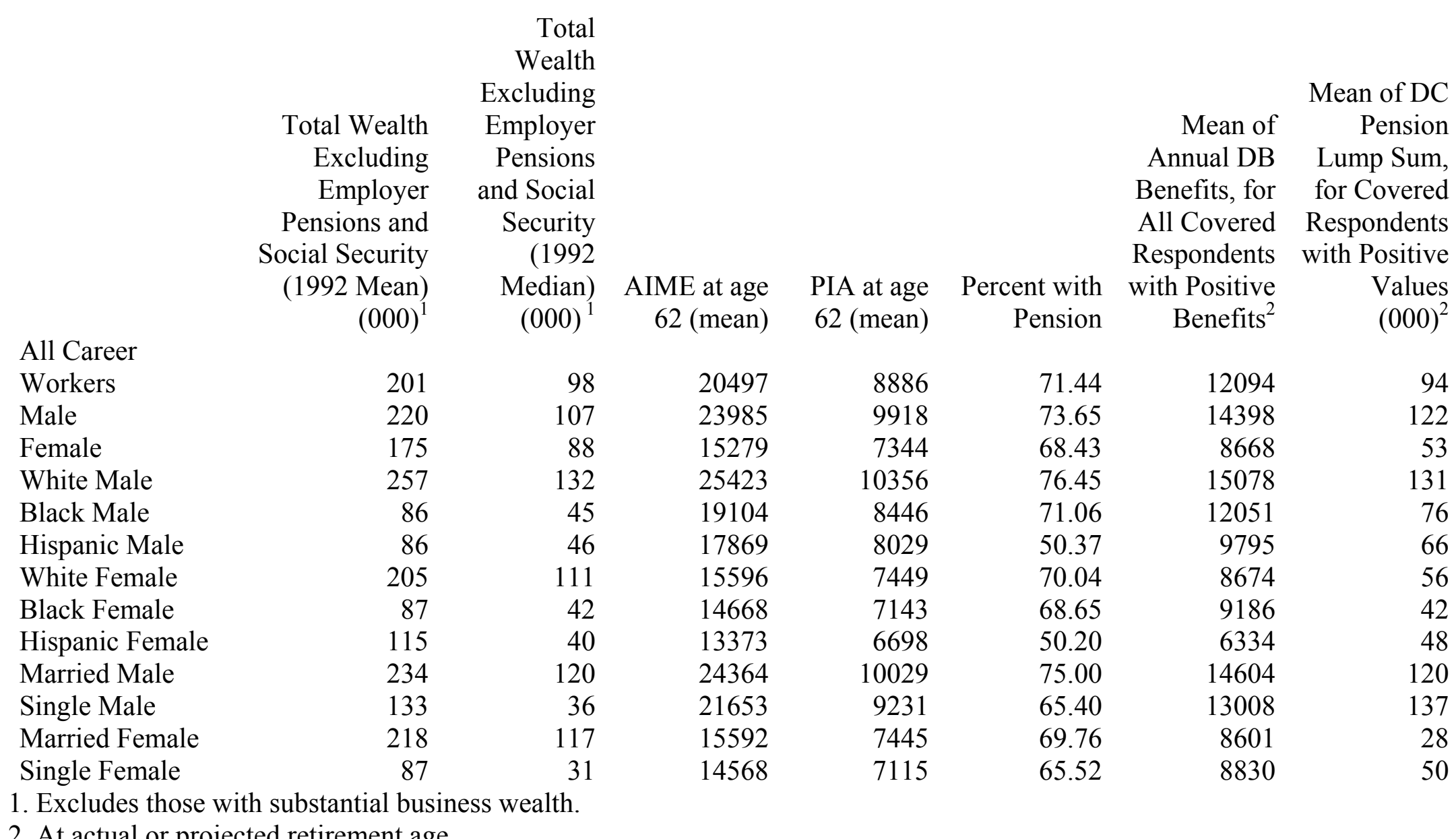


Table 16: Estimation of Parameters of the Utility Function For Long Term Married Males, All Races

\begin{tabular}{llrr} 
Symbol & \multicolumn{1}{c}{ Description } & $\begin{array}{r}\text { Coefficient } \\
\text { Value }\end{array}$ & t-statistic \\
$\sigma_{\varepsilon}$ & Std. Dev. Of Epsilon & 4.88 & 9.2437 \\
$\delta_{0}$ & Constant & -3.05 & -5.6029 \\
$\delta_{1}$ & Age & 0.68 & 3.3981 \\
$\beta_{0}$ & Constant & -10.346 & -158.037 \\
$\beta_{1}$ & Age & 0.113 & 4.7524 \\
$\beta_{2}$ & Health & 3.65 & 4.9774 \\
$\beta_{3}$ & Vintage & 0.03 & 0.3507 \\
$\alpha$ & Consumption & -0.42 & -5.0027 \\
& & & \\
& Number obs. & & 2231 \\
& q: & & 69.584
\end{tabular}


Table 17: Estimation of Parameters of the Utility Function For Long Term Married Females, All Races

\begin{tabular}{llrr} 
Symbol & \multicolumn{1}{c}{ Description } & $\begin{array}{c}\text { Coefficient } \\
\text { Value }\end{array}$ & t-statistic \\
$\sigma_{\varepsilon}$ & Std. Dev. Of Epsilon & 5.52 & 9.4347 \\
$\delta_{0}$ & Constant & -2.10 & -2.0368 \\
$\delta_{1}$ & Age & 0.16 & 2.0827 \\
$\beta_{0}$ & Constant & -9.605 & -86.4343 \\
$\beta_{1}$ & Age & 0.174 & 2.8885 \\
$\beta_{2}$ & Health & 2.04 & 2.5493 \\
$\beta_{3}$ & Vintage & 0.10 & 1.1121 \\
$\alpha$ & Consumption & 0.21 & 1.9360 \\
& & & \\
& Number obs. & & 1417 \\
& q: & & 81.89
\end{tabular}


Table 18: Estimation of Parameters of the Utility Function For Long Term Married Males, Including Variables Reflecting Ethnicity and Race

\begin{tabular}{llrr} 
Symbol & \multicolumn{1}{c}{ Description } & $\begin{array}{r}\text { Coefficient } \\
\text { Value }\end{array}$ & t-statistic \\
$\sigma_{\varepsilon}$ & Std. Dev. Of Epsilon & 4.80 & 9.5168 \\
$\delta_{0}$ & Constant & -2.99 & -5.3178 \\
$\delta_{1}$ & Age & 0.64 & 3.3888 \\
$\beta_{0}$ & Constant & -10.366 & -160.012 \\
& Black & -0.046 & -0.2926 \\
& Hispanic & -0.245 & -0.6028 \\
$\beta_{1}$ & Age & 0.138 & 4.2226 \\
& Age*Black & 0.105 & 0.5409 \\
& Age*Hispanic & 0.148 & 0.6536 \\
$\beta_{2}$ & Health & 3.28 & 4.6993 \\
$\beta_{3}$ & Vintage & 0.06 & 0.7576 \\
$\alpha$ & Consumption & -0.42 & -5.2671 \\
& & & \\
& Number obs. & & 2231 \\
& q: & & 75.682
\end{tabular}


Table 19: Simulated Effects for Men and Women of Different Utility Function Parameters and Different Circumstances on Retirement from Full Time Work

Retired from Full Time Work

\begin{tabular}{|c|c|c|c|c|c|c|c|c|}
\hline & \multicolumn{2}{|c|}{ Men's Utility Function } & \multicolumn{2}{|c|}{ Women's Utility Function } & \multicolumn{2}{|c|}{ Men's Utility Function } & \multicolumn{2}{|c|}{ Women's Utility Function } \\
\hline & & Women's & & Women's & & Women's & & Women's \\
\hline Age & $\begin{array}{r}\text { Men's Circum- } \\
\text { stances }\end{array}$ & $\begin{array}{l}\text { Circum- } \\
\text { stances }\end{array}$ & $\begin{array}{r}\text { Men's Circum- } \\
\text { stances }\end{array}$ & $\begin{array}{r}\text { Circum- } \\
\text { stances }\end{array}$ & $\begin{array}{r}\text { Men's Circum- } \\
\text { stances }\end{array}$ & $\begin{array}{l}\text { Circum- } \\
\text { stances }\end{array}$ & $\begin{array}{r}\text { Men's Circum- } \\
\text { stances }\end{array}$ & $\begin{array}{r}\text { Circum- } \\
\text { stances }\end{array}$ \\
\hline 50 & 2.6 & 1.6 & 5.5 & 7.5 & 1.6 & 1.2 & 3.5 & 4.9 \\
\hline 51 & 3.8 & 2.4 & 7.8 & 10.2 & 2.3 & 1.7 & 5.0 & 6.8 \\
\hline 52 & 5.2 & 3.3 & 10.4 & 13.4 & 3.2 & 2.2 & 6.9 & 8.9 \\
\hline 53 & 6.7 & 4.7 & 13.4 & 17.2 & 4.3 & 3.2 & 9.2 & 11.7 \\
\hline 54 & 8.6 & 6.1 & 17.1 & 21.0 & 5.8 & 4.0 & 12.0 & 14.5 \\
\hline 55 & 11.9 & 8.3 & 22.6 & 26.4 & 8.2 & 5.6 & 16.3 & 18.6 \\
\hline 56 & 15.0 & 10.4 & 27.9 & 31.6 & 10.6 & 7.1 & 20.5 & 22.6 \\
\hline 57 & 18.8 & 12.8 & 33.7 & 37.3 & 13.5 & 8.7 & 25.3 & 27.1 \\
\hline 58 & 23.2 & 15.6 & 40.0 & 43.5 & 17.1 & 10.6 & 30.8 & 32.1 \\
\hline 59 & 28.0 & 19.1 & 46.3 & 49.6 & 20.9 & 12.9 & 36.3 & 37.1 \\
\hline 60 & 35.1 & 24.2 & 54.2 & 56.9 & 26.5 & 16.3 & 43.3 & 43.3 \\
\hline 61 & 41.0 & 28.9 & 60.7 & 63.1 & 31.3 & 19.3 & 49.4 & 48.8 \\
\hline 62 & 53.1 & 40.1 & 69.9 & 71.4 & 39.5 & 24.0 & 58.0 & 55.5 \\
\hline 63 & 58.0 & 44.5 & 74.2 & 75.4 & 43.2 & 26.3 & 62.5 & 59.5 \\
\hline 64 & 63.2 & 50.1 & 78.6 & 79.9 & 47.4 & 29.5 & 67.4 & 64.1 \\
\hline 65 & 71.2 & 57.8 & 84.1 & 84.8 & 54.3 & 34.9 & 73.2 & 69.8 \\
\hline 66 & 77.0 & 65.2 & 87.9 & 88.7 & 59.4 & 41.8 & 77.6 & 75.6 \\
\hline 67 & 81.8 & 71.3 & 91.0 & 91.6 & 63.7 & 46.3 & 81.7 & 79.6 \\
\hline 68 & 86.2 & 77.9 & 93.7 & 94.2 & 68.1 & 51.9 & 85.7 & 83.9 \\
\hline 69 & 90.3 & 83.2 & 95.6 & 96.0 & 74.3 & 60.3 & 89.0 & 87.8 \\
\hline
\end{tabular}


Table 20: Differences in Simulated Retirements from Full Time Work for Men and Women Using Different Utility Function Parameters and Different Circumstances

\begin{tabular}{|c|c|c|c|c|c|c|}
\hline Age & $\begin{array}{l}\text { Actual Difference } \\
\text { Women minus Men }\end{array}$ & $\begin{array}{r}\text { Women's Utility, } \\
\text { Women's } \\
\text { Circumstances } \\
\text { minus Men's Utility, } \\
\text { Men's } \\
\text { Circumstances }\end{array}$ & $\begin{array}{r}\text { Men's Utility, } \\
\text { Women's } \\
\text { Circumstances } \\
\text { minus Men's Utility, } \\
\text { Men's } \\
\text { Circumstances }\end{array}$ & $\begin{array}{r}\text { Women's Utility, } \\
\text { Women's } \\
\text { Circumstance minus } \\
\text { Women's Utility, } \\
\text { Men's Circumstance }\end{array}$ & $\begin{array}{r}\text { Women's Utility } \\
\text { Function, Men's } \\
\text { Circumstances - } \\
\text { Men's Utility } \\
\text { Function, Men's } \\
\text { Circumstances }\end{array}$ & $\begin{array}{r}\text { Women's Utility } \\
\text { Function, Women's } \\
\text { Circumstances - } \\
\text { Men's Utility } \\
\text { Function, Women's } \\
\text { Circumstances }\end{array}$ \\
\hline 50 & 8.1 & 4.9 & -1.0 & 2.0 & 2.9 & 5.9 \\
\hline 51 & 9.0 & 6.4 & -1.4 & 2.4 & 4.0 & 7.8 \\
\hline 52 & 8.7 & 8.2 & -1.9 & 3.0 & 5.2 & 10.1 \\
\hline 53 & 10.3 & 10.5 & -2.0 & 3.8 & 6.7 & 12.5 \\
\hline 54 & 11.3 & 12.4 & -2.5 & 3.9 & 8.5 & 14.9 \\
\hline 55 & 13.0 & 14.5 & -3.6 & 3.8 & 10.7 & 18.1 \\
\hline 56 & 12.2 & 16.6 & -4.6 & 3.7 & 12.9 & 21.2 \\
\hline 57 & 13.6 & 18.5 & -6.0 & 3.6 & 14.9 & 24.5 \\
\hline 58 & 15.1 & 20.3 & -7.6 & 3.5 & 16.8 & 27.9 \\
\hline 59 & 14.6 & 21.6 & -8.9 & 3.3 & 18.3 & 30.5 \\
\hline 60 & 14.8 & 21.8 & -10.9 & 2.7 & 19.1 & 32.7 \\
\hline 61 & 16.5 & 22.1 & -12.1 & 2.4 & 19.7 & 34.2 \\
\hline 62 & 15.7 & 18.3 & -13.0 & 1.5 & 16.8 & 31.3 \\
\hline 63 & 17.2 & 17.4 & -13.5 & 1.2 & 16.2 & 30.9 \\
\hline 64 & 16.0 & 16.7 & -13.1 & 1.3 & 15.4 & 29.8 \\
\hline 65 & 12.5 & 13.6 & -13.4 & 0.7 & 12.9 & 27.0 \\
\hline 66 & 9.8 & 11.7 & -11.8 & 0.8 & 10.9 & 23.5 \\
\hline 67 & 9.4 & 9.8 & -10.5 & 0.6 & 9.2 & 20.3 \\
\hline 68 & 7.5 & 8.0 & -8.3 & 0.5 & 7.5 & 16.3 \\
\hline 69 & 6.1 & 5.7 & -7.1 & 0.4 & 5.3 & 12.8 \\
\hline
\end{tabular}


Table 21: Differences in Simulated Complete Retirements for Men and Women Using Different Utility Function Parameters and Different Circumstances

\begin{tabular}{|c|c|c|c|c|c|c|}
\hline Age & $\begin{array}{l}\text { Actual Difference } \\
\text { Women minus Men }\end{array}$ & $\begin{array}{r}\text { Women's Utility, } \\
\text { Women's } \\
\text { Circumstances } \\
\text { minus Men's Utility, } \\
\text { Men's } \\
\text { Circumstances }\end{array}$ & $\begin{array}{r}\text { Men's Utility, } \\
\text { Women's } \\
\text { Circumstances } \\
\text { minus Men's Utility, } \\
\text { Men's } \\
\text { Circumstances }\end{array}$ & $\begin{array}{r}\text { Women's Utility, } \\
\text { Women's } \\
\text { Circumstance minus } \\
\text { Women's Utility, } \\
\text { Men's Circumstance }\end{array}$ & $\begin{array}{r}\text { Women's Utility } \\
\text { Function, Men's } \\
\text { Circumstances - } \\
\text { Men's Utility } \\
\text { Function, Men's } \\
\text { Circumstances }\end{array}$ & $\begin{array}{r}\text { Women's Utility } \\
\text { Function, Women's } \\
\text { Circumstances - } \\
\text { Men's Utility } \\
\text { Function, Women's } \\
\text { Circumstances }\end{array}$ \\
\hline 50 & 5.3 & 3.3 & -0.4 & 1.4 & 1.9 & 3.7 \\
\hline 51 & 6.3 & 4.5 & -0.6 & 1.8 & 2.7 & 5.1 \\
\hline 52 & 5.1 & 5.7 & -1.0 & 2.0 & 3.7 & 6.7 \\
\hline 53 & 8.2 & 7.4 & -1.1 & 2.5 & 4.9 & 8.5 \\
\hline 54 & 10.2 & 8.7 & -1.8 & 2.5 & 6.2 & 10.5 \\
\hline 55 & 10.8 & 10.4 & -2.6 & 2.3 & 8.1 & 13.0 \\
\hline 56 & 10.1 & 12.0 & -3.5 & 2.1 & 9.9 & 15.5 \\
\hline 57 & 9.6 & 13.6 & -4.8 & 1.8 & 11.8 & 18.4 \\
\hline 58 & 10.8 & 15.0 & -6.5 & 1.3 & 13.7 & 21.5 \\
\hline 59 & 11.6 & 16.2 & -8.0 & 0.8 & 15.4 & 24.2 \\
\hline 60 & 10.6 & 16.8 & -10.2 & 0.0 & 16.8 & 27.0 \\
\hline 61 & 12.4 & 17.5 & -12.0 & -0.6 & 18.1 & 29.5 \\
\hline 62 & 13.7 & 16.0 & -15.5 & -2.5 & 18.5 & 31.5 \\
\hline 63 & 15.4 & 16.3 & -16.9 & -3 & 19.3 & 33.2 \\
\hline 64 & 14.3 & 16.7 & -17.9 & -3.3 & 20 & 34.6 \\
\hline 65 & 13.4 & 15.5 & -19.4 & -3.4 & 18.9 & 34.9 \\
\hline 66 & 11.6 & 16.2 & -17.6 & -2.0 & 18.2 & 33.8 \\
\hline 67 & 9.9 & 15.9 & -17.4 & -2.1 & 18.0 & 33.3 \\
\hline 68 & 10.4 & 15.8 & -16.2 & -1.8 & 17.6 & 32.0 \\
\hline 69 & 6.4 & 13.5 & -14.0 & -1.2 & 14.7 & 27.5 \\
\hline
\end{tabular}


Table 22: Simulated Effects of Differences in Time Preference and Different Circumstances by Race and Ethnicity on Complete Retirement

(Using Utility function parameters for Married Males from Equation with No Racial Binaries in Beta Vector)

\begin{tabular}{|c|c|c|c|c|c|c|c|}
\hline \multirow{2}{*}{$\begin{array}{l}\text { Time Preference } \\
\text { Circumstances }\end{array}$} & \multirow[b]{2}{*}{ White } & \multirow{2}{*}{$\begin{array}{l}\text { White } \\
\text { Black }\end{array}$} & \multirow[b]{2}{*}{ Hispanic } & \multicolumn{2}{|c|}{ Black } & \multicolumn{2}{|c|}{ Hispanic } \\
\hline & & & & White & Black & White & Hispanic \\
\hline \multicolumn{8}{|l|}{ Age } \\
\hline 50 & 2.7 & 3.6 & 2.4 & 9.8 & 2.6 & 10.6 & 2.0 \\
\hline 51 & 3.9 & 4.3 & 2.8 & 11.8 & 3.8 & 13.0 & 2.8 \\
\hline 52 & 5.3 & 5.5 & 3.8 & 14.1 & 5.4 & 15.4 & 3.9 \\
\hline 53 & 6.8 & 7.3 & 4.7 & 16.5 & 6.8 & 18.4 & 4.6 \\
\hline 54 & 8.9 & 9.2 & 5.8 & 19.3 & 8.4 & 21.5 & 5.8 \\
\hline 55 & 12.4 & 11.3 & 7.7 & 24.1 & 11.3 & 25.9 & 7.6 \\
\hline 56 & 15.7 & 14.1 & 9.7 & 28.0 & 14.1 & 29.8 & 9.7 \\
\hline 57 & 19.6 & 17.0 & 12.3 & 32.2 & 17.9 & 34.0 & 12.2 \\
\hline 58 & 24.1 & 20.3 & 15.2 & 36.7 & 21.8 & 38.5 & 15.8 \\
\hline 59 & 29.0 & 24.6 & 18.0 & 41.4 & 27.2 & 43.1 & 19.6 \\
\hline 60 & 36.2 & 33.0 & 23.0 & 47.5 & 34.9 & 49.2 & 24.1 \\
\hline 61 & 42.2 & 38.6 & 28.4 & 52.6 & 41.0 & 54.5 & 30.0 \\
\hline 62 & 53.0 & 48.9 & 38.7 & 64.3 & 58.0 & 66.7 & 47.4 \\
\hline 63 & 57.7 & 53.2 & 43.2 & 68.7 & 63.3 & 71.0 & 52.5 \\
\hline 64 & 63.0 & 58.9 & 48.5 & 73.0 & 68.2 & 75.1 & 57.6 \\
\hline 65 & 71.6 & 67.6 & 56.2 & 78.8 & 74.1 & 80.7 & 62.9 \\
\hline 66 & 77.5 & 74.3 & 62.2 & 83.0 & 79.0 & 84.5 & 69.0 \\
\hline 67 & 82.3 & 79.3 & 68.1 & 86.6 & 83.1 & 87.8 & 74.5 \\
\hline 68 & 86.6 & 83.9 & 74.4 & 89.9 & 87.4 & 90.8 & 80.8 \\
\hline 69 & 90.3 & 87.9 & 79.9 & 92.9 & 91.5 & 93.6 & 87.7 \\
\hline
\end{tabular}


Table 23: Simulated Effects of Differences in Circumstances by Race and Ethnicity on Complete Retirement (Using Utility function parameters for Married Males from Equation with No Racial Binaries in Beta Vector)

$\begin{array}{crrrr}\text { Time Preference } & \text { White } & \text { White } & \text { Black } & \text { Hispanic } \\ & & & \text { Hispanic Minus } \\ \text { Circumstances } & \text { Black minus White } & \text { Hispanic Minus } & \text { White } \\ \text { Age } & & \text { White } & \text { Black minus White } & -8.6 \\ 50 & 0.9 & -0.3 & -7.2 & -10.2 \\ 51 & 0.4 & -1.1 & -8 & -11.5 \\ 52 & 0.2 & -1.5 & -8.7 & -13.8 \\ 53 & 0.5 & -2.1 & -9.7 & -15.7 \\ 54 & 0.3 & -3.1 & -10.9 & -18.3 \\ 55 & -1.1 & -4.7 & -12.8 & -20.1 \\ 56 & -1.6 & -6 & -13.9 & -21.8 \\ 57 & -2.6 & -14.3 & -22.7 \\ 58 & -3.8 & -8.9 & -14.9 & -23.5 \\ 59 & -4.4 & -11 & -14.2 & -25.1 \\ 60 & -3.2 & -13.2 & -12.6 & -24.5 \\ 61 & -3.6 & -13.8 & -11.6 & -19.3 \\ 62 & -4.1 & -14.3 & -6.3 & -18.5 \\ 63 & -4.5 & -14.5 & -5.4 & -17.5 \\ 64 & -4.1 & -14.5 & -4.8 & -17.8 \\ 65 & -4 & -15.4 & -4.7 & -15.5 \\ 66 & -3.2 & -15.3 & -4 & -13.3 \\ 67 & -3 & -14.2 & -3.5 & -10 \\ 68 & -2.7 & -12.2 & -1.4 & -5.9\end{array}$


Table 24: Simulated Effects of Differences in Time Preference by Race and Ethnicity on Complete Retirement (Using Utility Function Parameters for Married Males from Equation with No Racial Binaries in Beta Vector)

\begin{tabular}{|c|c|c|c|c|}
\hline Time Preference & $\begin{array}{r}\text { Black Minus } \\
\text { White }\end{array}$ & $\begin{array}{r}\text { Hispanic Minus } \\
\text { White }\end{array}$ & $\begin{array}{r}\text { Black Minus } \\
\text { White }\end{array}$ & $\begin{array}{r}\text { Hispanic Minus } \\
\text { White }\end{array}$ \\
\hline Circumstances & White & White & Black & Hispanic \\
\hline \multicolumn{5}{|l|}{ Age } \\
\hline 50 & 7.1 & 7.9 & -1 & -0.4 \\
\hline 51 & 7.9 & 9.1 & -0.5 & 0 \\
\hline 52 & 8.8 & 10.1 & -0.1 & 0.1 \\
\hline 53 & 9.7 & 11.6 & -0.5 & -0.1 \\
\hline 54 & 10.4 & 12.6 & -0.8 & 0 \\
\hline 55 & 11.7 & 13.5 & 0 & -0.1 \\
\hline 56 & 12.3 & 14.1 & 0 & 0 \\
\hline 57 & 12.6 & 14.4 & 0.9 & -0.1 \\
\hline 58 & 12.6 & 14.4 & 1.5 & 0.6 \\
\hline 59 & 12.4 & 14.1 & 2.6 & 1.6 \\
\hline 60 & 11.3 & 13 & 1.9 & 1.1 \\
\hline 61 & 10.4 & 12.3 & 2.4 & 1.6 \\
\hline 62 & 11.3 & 13.7 & 9.1 & 8.7 \\
\hline 63 & 11 & 13.3 & 10.1 & 9.3 \\
\hline 64 & 10 & 12.1 & 9.3 & 9.1 \\
\hline 65 & 7.2 & 9.1 & 6.5 & 6.7 \\
\hline 66 & 5.5 & 7 & 4.7 & 6.8 \\
\hline 67 & 4.3 & 5.5 & 3.8 & 6.4 \\
\hline 68 & 3.3 & 4.2 & 3.5 & 6.4 \\
\hline 69 & 2.6 & 3.3 & 3.6 & 7.8 \\
\hline
\end{tabular}


Appendix Table 1: Retirements for Career and Non-Career Workers Combined, Both Genders, All Races, All Marital Status Groups

\begin{tabular}{rrrrrr}
\multicolumn{5}{c}{ Retirements } & \multicolumn{3}{c}{ Percent Retired } \\
& From & \multicolumn{3}{c}{ From } \\
& Full & Into Full & Full & \\
& Time & Time & Time & Completely & Observations \\
Age & Work & Retirement & Work & Retired & By Age \\
50 & 32.0 & 22.3 & 32.0 & 22.3 & 2021 \\
51 & -0.1 & -0.6 & 31.9 & 21.6 & 2692 \\
52 & -1.2 & -0.7 & 30.7 & 20.9 & 3325 \\
53 & 1.3 & 1.7 & 32.0 & 22.6 & 3842 \\
54 & 1.4 & 1.0 & 33.4 & 23.6 & 4292 \\
55 & 2.1 & 1.8 & 35.6 & 25.4 & 4666 \\
56 & 1.4 & 1.7 & 37.0 & 27.1 & 5087 \\
57 & 2.0 & 1.3 & 39.0 & 28.4 & 5334 \\
58 & 2.4 & 2.0 & 41.4 & 30.4 & 5568 \\
59 & 2.9 & 2.4 & 44.3 & 32.8 & 5739 \\
60 & 4.9 & 4.4 & 49.2 & 37.3 & 5637 \\
61 & 5.4 & 4.5 & 54.6 & 41.7 & 4996 \\
62 & 11.0 & 10.3 & 65.6 & 52.0 & 4468 \\
63 & 5.0 & 4.1 & 70.6 & 56.2 & 4010 \\
64 & 4.2 & 5.1 & 74.9 & 61.3 & 3517 \\
65 & 6.9 & 6.1 & 81.8 & 67.4 & 2978 \\
66 & 2.8 & 2.4 & 84.6 & 69.8 & 2475 \\
67 & 2.1 & 2.4 & 86.7 & 72.3 & 2030 \\
68 & 2.0 & 1.7 & 88.7 & 74.0 & 1604 \\
69 & 1.3 & 2.5 & 90.0 & 76.5 & 1176
\end{tabular}

Observations: 12,652 
Appendix Table 2: Retirements for Career Workers, Males, All Races, Married

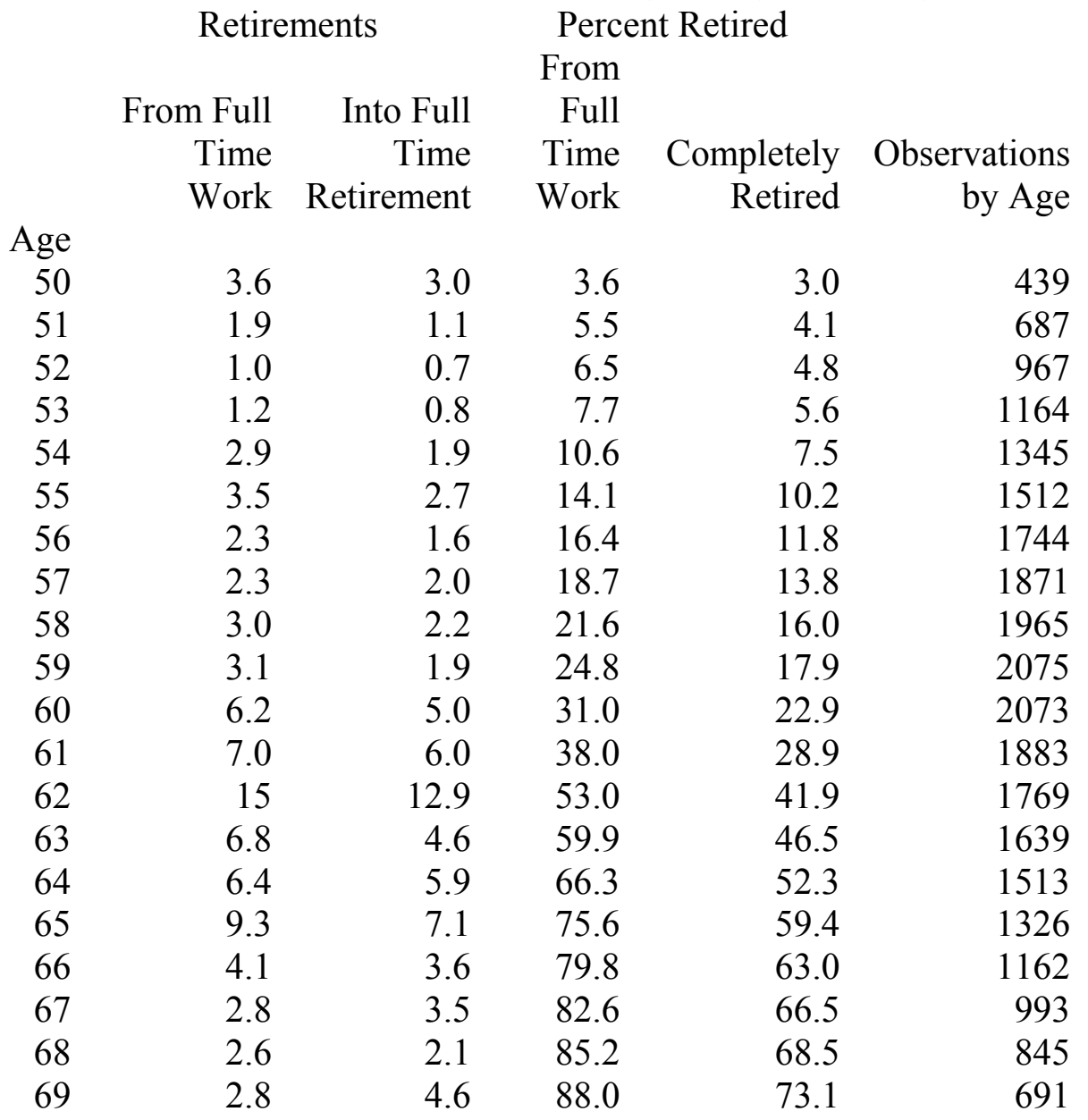

Observations: 4348 
Appendix Table 3: Retirements for Career Workers, Males, All Races, Single

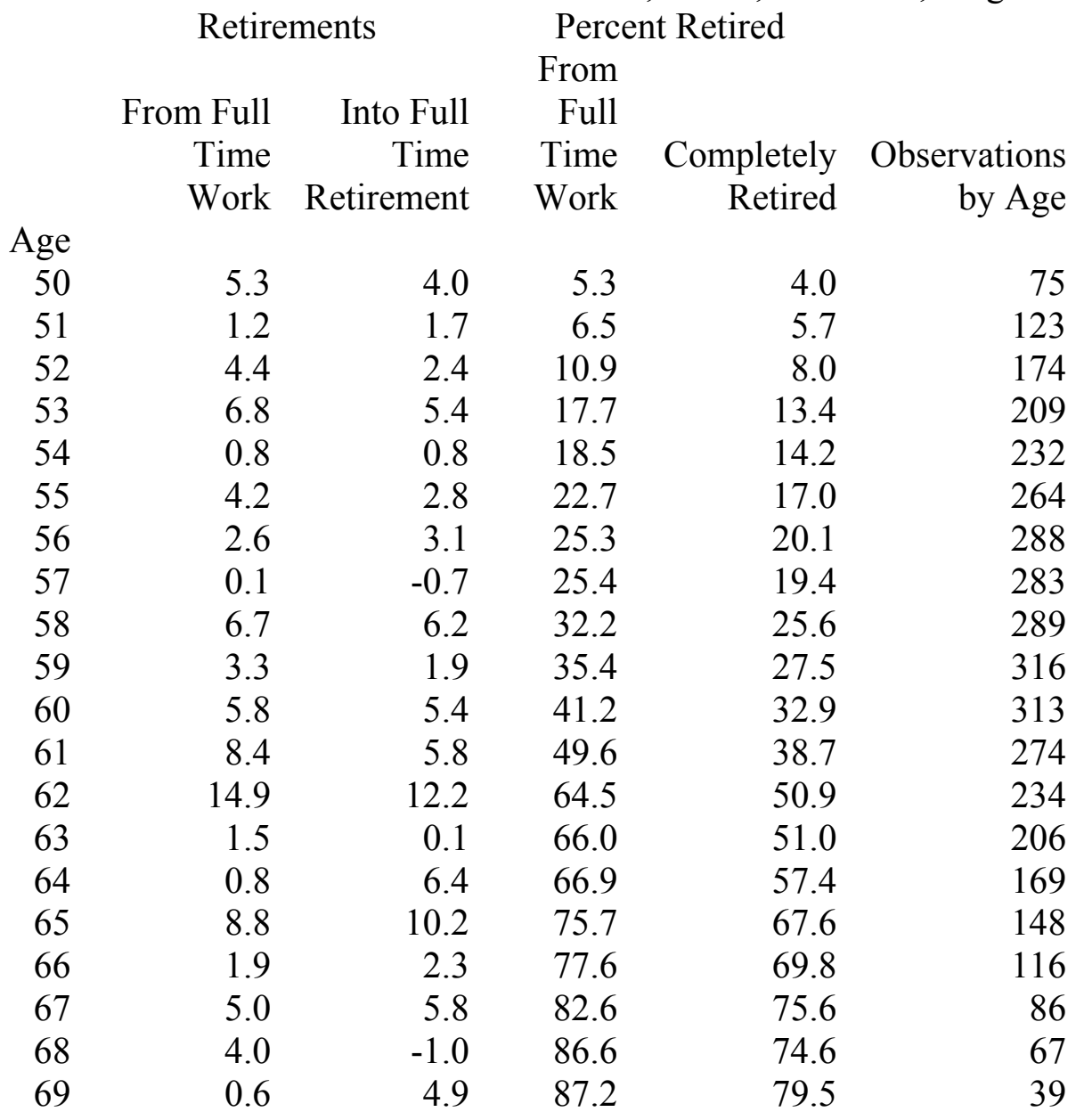

Observations: 711 
Appendix Table 4: Retirements for Career Workers, Females, All Races, Married

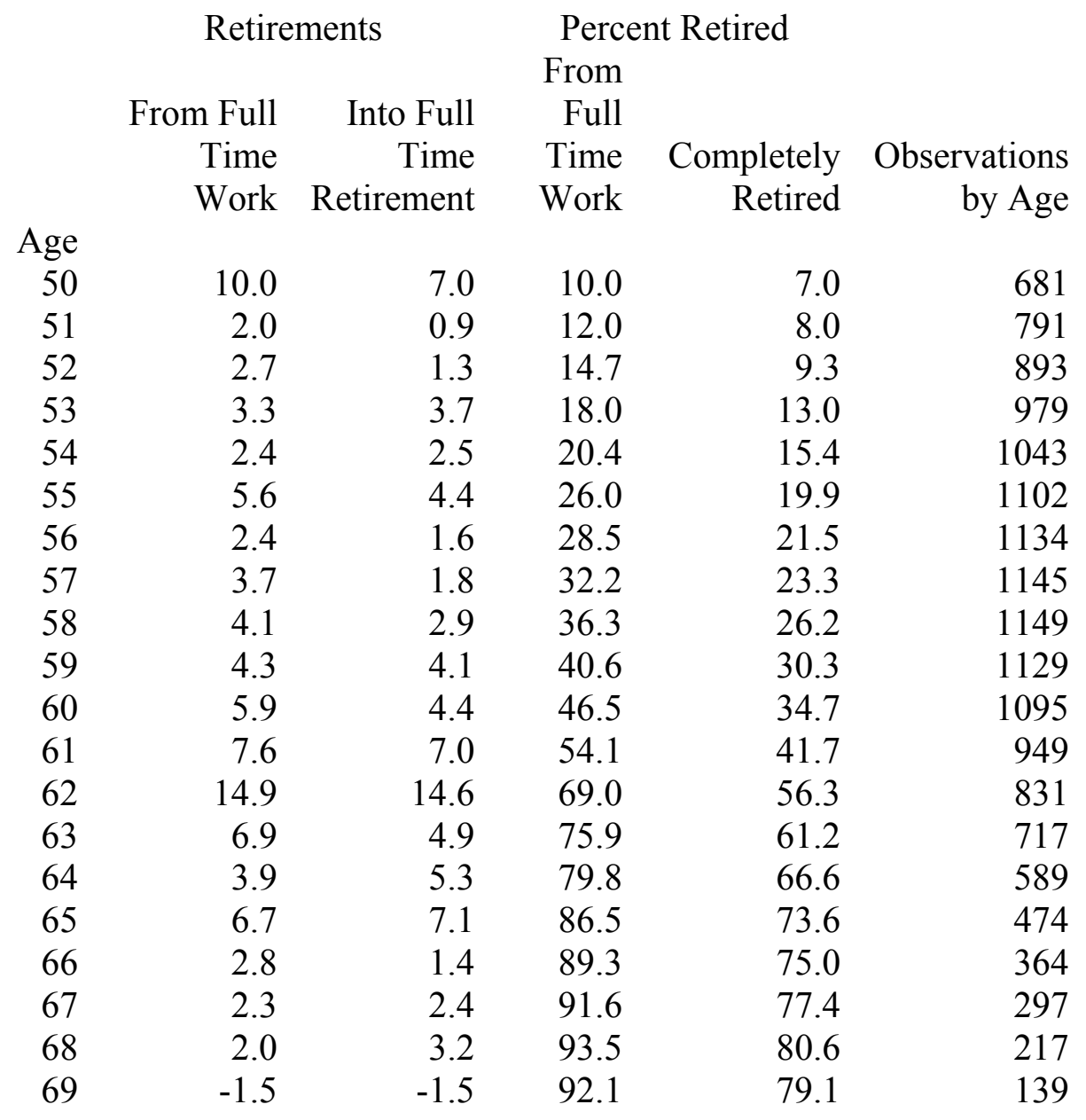

Observations: 2543 
Appendix Table 5: Retirements for Career Workers, Females, All Races, Single

\begin{tabular}{rrrrrr}
\multicolumn{5}{c}{ Retirements } & \multicolumn{5}{c}{ Percent Retired } \\
& \multicolumn{5}{c}{ From } \\
& $\begin{array}{r}\text { From Full } \\
\text { Time } \\
\text { Work }\end{array}$ & $\begin{array}{r}\text { Into Full } \\
\text { Time }\end{array}$ & $\begin{array}{r}\text { Full } \\
\text { Time }\end{array}$ & $\begin{array}{r}\text { Completely } \\
\text { Retirement }\end{array}$ & $\begin{array}{r}\text { Observations } \\
\text { Wy Age }\end{array}$ \\
Age & & & & & \\
50 & 8.1 & 7.4 & 8.1 & 7.4 & 149 \\
51 & 0.1 & -1.0 & 8.1 & 6.4 & 234 \\
52 & -0.5 & -1.4 & 7.6 & 5.0 & 317 \\
53 & 2.7 & 2.7 & 10.2 & 7.7 & 362 \\
54 & 3.9 & 1.2 & 14.2 & 9.0 & 424 \\
55 & 2.9 & 1.8 & 17.0 & 10.8 & 464 \\
56 & 2.0 & 2.4 & 19.1 & 13.2 & 530 \\
57 & 1.0 & 2.0 & 20.1 & 15.2 & 567 \\
58 & 1.1 & 0.0 & 21.2 & 15.1 & 628 \\
59 & 6.2 & 5.2 & 27.4 & 20.3 & 646 \\
60 & 6.2 & 5.2 & 33.6 & 25.5 & 631 \\
61 & 7.1 & 4.5 & 40.7 & 30.0 & 560 \\
62 & 11.4 & 9.0 & 52.2 & 39.0 & 464 \\
63 & 7.4 & 6.8 & 59.6 & 45.8 & 408 \\
64 & 5.2 & 7.7 & 64.8 & 53.5 & 355 \\
65 & 10.6 & 7.6 & 75.4 & 61.1 & 293 \\
66 & 5.2 & 4.6 & 80.6 & 65.7 & 242 \\
67 & 1.2 & 3.6 & 81.8 & 69.3 & 192 \\
68 & 2.8 & 2.8 & 84.6 & 72.1 & 136 \\
69 & 1.0 & 2.9 & 85.5 & 75.0 & 76
\end{tabular}

Observations: 1166 
Appendix Table 6: Retirement, Long Term Married Men: Utility Function Includes Indicators of Race and Ethnicity and Interactions with Age

\begin{tabular}{|c|c|c|c|c|c|c|c|c|c|c|c|c|}
\hline \multirow[b]{3}{*}{ Age } & \multicolumn{6}{|c|}{ From Full Time Work } & \multicolumn{6}{|c|}{ Completely Retired } \\
\hline & \multicolumn{3}{|c|}{ Observed } & \multicolumn{3}{|c|}{ Predicted } & \multicolumn{3}{|c|}{ Observed } & \multicolumn{3}{|c|}{ Predicted } \\
\hline & White & Black & Hispanic & White & Black & Hispanic & White & Black & Hispanic & White & Black & Hispanic \\
\hline 50 & 3.4 & 11.8 & 4.5 & 2.8 & 1.5 & 0.5 & 2.5 & 11.8 & 4.5 & 1.8 & 0.5 & 0.4 \\
\hline 51 & 4.5 & 6.1 & 8.3 & 4.0 & 2.2 & 0.9 & 2.7 & 6.1 & 5.6 & 2.5 & 0.8 & 0.7 \\
\hline 52 & 6.7 & 8.3 & 13.8 & 5.4 & 3.4 & 1.4 & 4.5 & 8.3 & 10.3 & 3.5 & 1.2 & 1.1 \\
\hline 53 & 8.9 & 13.0 & 13.1 & 6.9 & 4.5 & 2.0 & 5.9 & 11.1 & 8.2 & 4.6 & 1.9 & 1.5 \\
\hline 54 & 11.0 & 18.3 & 12.9 & 9.1 & 6.4 & 2.9 & 6.9 & 15.0 & 9.7 & 6.2 & 3.0 & 2.3 \\
\hline 55 & 15.2 & 14.9 & 10.3 & 12.6 & 9.3 & 4.3 & 10.7 & 10.4 & 10.3 & 8.8 & 4.8 & 3.4 \\
\hline 56 & 16.5 & 20.9 & 14.1 & 15.8 & 12.5 & 6.5 & 12.4 & 17.6 & 9.4 & 11.4 & 7.0 & 5.0 \\
\hline 57 & 19.9 & 26.6 & 22.2 & 19.7 & 16.5 & 9.4 & 15.3 & 19.3 & 16.7 & 14.5 & 9.9 & 7.2 \\
\hline 58 & 23.4 & 29.1 & 20.8 & 24.2 & 21.0 & 13.0 & 17.9 & 19.1 & 16.9 & 18.2 & 13.5 & 10.1 \\
\hline 59 & 27.1 & 31.9 & 24.1 & 29.1 & 26.7 & 17.7 & 19.7 & 22.7 & 20.3 & 22.1 & 17.8 & 13.5 \\
\hline 60 & 33.3 & 35.4 & 30.8 & 36.2 & 34.9 & 23.3 & 26.2 & 29.2 & 24.4 & 28.0 & 24.4 & 17.7 \\
\hline 61 & 39.9 & 41.9 & 34.7 & 42.1 & 42.2 & 30.3 & 32.0 & 33.3 & 29.3 & 32.7 & 30.6 & 23.1 \\
\hline 62 & 55.2 & 58.7 & 43.1 & 53.0 & 58.5 & 46.2 & 44.0 & 53.3 & 36.9 & 40.4 & 42.9 & 34.0 \\
\hline 63 & 61.3 & 60.9 & 44.7 & 57.7 & 65.1 & 53.4 & 47.5 & 54.3 & 40.4 & 44.1 & 48.4 & 39.5 \\
\hline 64 & 68.3 & 63.4 & 54.5 & 62.9 & 71.1 & 60.7 & 54.8 & 56.1 & 47.7 & 48.3 & 54.5 & 45.6 \\
\hline 65 & 76.1 & 81.1 & 68.6 & 71.6 & 76.9 & 66.9 & 60.6 & 66.2 & 62.9 & 55.5 & 61.5 & 52.7 \\
\hline 66 & 80.5 & 86.4 & 73.5 & 77.4 & 82.2 & 74.0 & 64.7 & 69.7 & 64.7 & 60.5 & 67.7 & 60.0 \\
\hline 67 & 83.6 & 87.0 & 78.1 & 82.3 & 86.7 & 80.5 & 67.8 & 69.6 & 71.9 & 64.7 & 72.4 & 66.7 \\
\hline 68 & 86.8 & 88.4 & 82.1 & 86.5 & 90.8 & 86.3 & 71.3 & 69.8 & 75.0 & 68.7 & 77.4 & 72.9 \\
\hline 69 & 88.5 & 89.2 & 84.2 & 90.2 & 94.2 & 92.0 & 75.5 & 81.1 & 73.7 & 73.9 & 84.0 & 81.9 \\
\hline
\end{tabular}

